\title{
Hybrid poplar yields in Québec: Implications for a sustainable forest zoning management system
}

\author{
by Julien Fortier ${ }^{1,2,3}$, Benoit Truax ${ }^{1}$, Daniel Gagnon ${ }^{1,2,4}$ and France Lambert ${ }^{1}$
}

\begin{abstract}
In the province of Québec, approximately 12000 ha of fast-growing poplar plantations are managed by industrials, while small private landowners have planted only 1000 ha. Most of these poplar plantations are established on clearcut forest sites (approx. $11000 \mathrm{ha}$ ). What are the yields of these hybrid poplar plantations? In this article, available yield data are presented and discussed in the context of a sustainable forest zoning management system. In southern Québec, three factors are highly correlated to yield for clones of various parentages: $\mathrm{NO}_{3}$ supply rate in riparian soils, elevation (or climate) and soil P availability in abandoned farmland soils. Many Québec forest sites, particularly in the boreal shield ecozone, have acidic soils and harsh climate, with low mineralization rates. They generally cannot fulfill the very high nutrient requirements of hybrid poplars. Within a forest zoning management system, hybrid poplar plantations and agroforestry should be located in priority in southern Québec landscapes, with low remaining natural forest cover, and where intensive agriculture is the dominant land-use. This strategy will increase biodiversity and the provision of ecosystem services. Elsewhere, intensive trembling aspen regeneration silviculture could be a sustainable alternative to forest conversion into hybrid poplar plantations.
\end{abstract}

Key words: afforestation, agroforestry, forest conversion, intensive aspen silviculture, ecosystem services, biodiversity, biomass

\section{RÉSUMÉ}

Au Québec, il existe approximativement 12000 ha de plantations de peuplier hybride aménagés par l'industrie et 1000 ha aménagés par des propriétaires privés. La plupart de ces plantations (environ 11000 ha) ont été aménagées sur des sites forestiers suite à une coupe totale. Quel est le rendement de ces plantations? Dans cet article, les données de rendement disponibles sont présentées et discutées dans une perspective de zonage d’aménagement forestier durable. Dans le sud du Québec, trois facteurs fortement corrélés au rendement de différents clones non apparentés ont été identifiés: le flux de $\mathrm{NO}_{3}$ dans les sols riverains, laltitude (climat) et le $\mathrm{P}$ disponible dans le sol des terres agricoles abandonnées. Plusieurs sites forestiers du Québec, particulièrement dans l'écozone du bouclier boréal, ont un sol acide, un climat rigoureux et un faible taux de minéralisation. Ces sites ne pourront pas satisfaire les exigences nutritionnelles élevées des peupliers hybrides. Dans une perspective de zonage d’aménagement forestier durable, les plantations et les systèmes agroforestiers de peuplier devraient, en priorité, être établis dans le sud du Québec dans les paysages d’agriculture intensive, là où le couvert forestier résiduel est faible. Cette stratégie permettra d’augmenter la biodiversité et la production de services écologiques. Ailleurs, la silviculture intensive du peuplier faux-tremble basée sur la régénération naturelle pourrait être une approche alternative et durable à la conversion de forêts en plantations de peuplier hybride.

Mots-clés : afforestation, agroforesterie, conversion de forêts, silviculture intensive du peuplier faux-tremble, services écologiques, biodiversité, biomasse

\footnotetext{
${ }^{1}$ Fiducie de recherche sur la forêt des Cantons-de-l'Est/Eastern Townships Forest Research Trust, 1 rue Principale, Saint-Benoît-du-Lac, QC, Canada, J0B 2M0

${ }^{2}$ Centre détude de la forêt (CEF), département des sciences biologiques, Université du Québec à Montréal, C.P. 8888 succ. Centre-ville, Montréal, QC, Canada, H3C 3P8

${ }^{3}$ Corresponding author. E-mail: fortier.julien@courrier.uqam.ca

${ }^{4}$ Department of Biology, University of Regina, 3737 Wascana Parkway, Regina, SK, Canada, S4S 0A2
} 


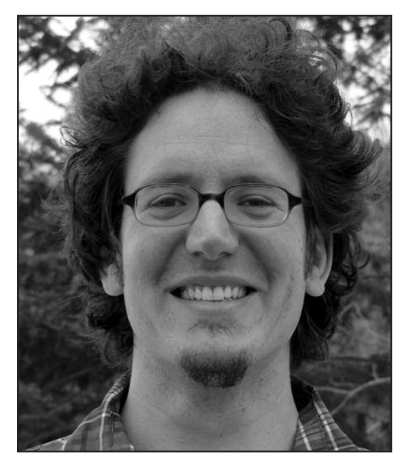

Julien Fortier

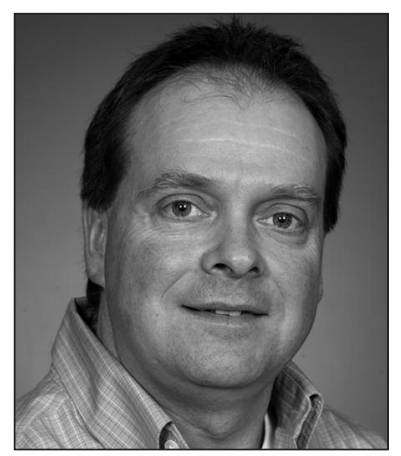

Benoit Truax

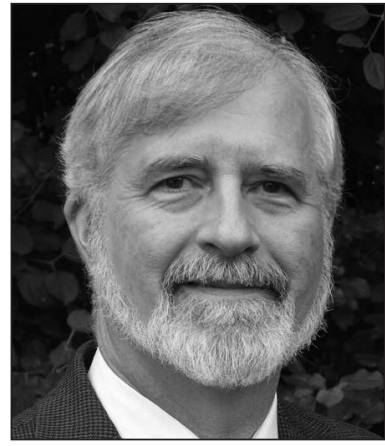

Daniel Gagnon

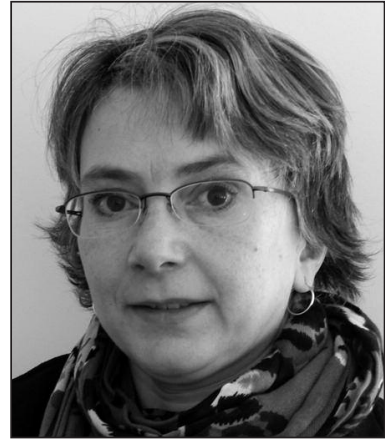

France Lambert

\section{Introduction}

The Government of Québec is in the process of implementing a forest zoning management system (Gouvernement du Québec 2008) (i.e., conservation zones, ecosystemic management zones and small intensive production zones; Hunter 1990). Legislation has confirmed this new approach through the Loi sur laménagement durable du territoire forestier (Québec 2011a). It appears that the solid arguments made in favour of forest zoning by Canadian researchers have been considered by Québec's decision makers (Binkley 1999; Messier et al. 2003, 2009; Montigny and MacLean 2006; Carmean 2007; Côté et al. 2010; Hartmann et al. 2010).

A key component of the zoning approach lies in the ability of land managers and landowners to highly intensify timber production on small portions of the landbase to make up for the harvests lost through increases in protected areas and the application of ecosystem management (Binkley 1999). Therefore, it is paramount that investments that are made to develop forestry plantations result in high increases, ideally at locations situated near transformation facilities and markets.

Moreover, in a globalized market, an effective shift to intensive production may be necessary to sustain Canada's competitiveness, as many tropical countries have a much more favourable climate for wood production (Park and Wilson 2007). For example, yields in tropical countries such as Brazil, South Africa, Uruguay, Congo and Zimbabwe can reach up to $40 \mathrm{~m}^{3} \mathrm{ha}^{-1}$ year-1 on five- to15-year rotations with Eucalyptus grandis W. Hill ex Maiden and eucalyptus hybrids (Cossalter and Pye-Smith 2003).

In Québec, fast-growing hybrid poplar plantations have often been proposed as a viable solution for producing high yields in temperate and boreal zones in areas dedicated to intensive production (Messier et al. 2003, Bilodeau-Gauthier et al. 2011). In 2003, the anticipated yields were $14 \mathrm{~m}^{3} \mathrm{ha}^{-1}$ year ${ }^{-1}$ on average sites, and $20 \mathrm{~m}^{3} \mathrm{ha}^{-1}$ year ${ }^{-1}$ on the best sites of southern Québec (Messier et al. 2003). In the boreal region, they were $12 \mathrm{~m}^{3} \mathrm{ha}^{-1}$ year $^{-1}$ on the best sites and $10 \mathrm{~m}^{3} \mathrm{ha}^{-1}$ year ${ }^{-1}$ on average sites (Messier et al. 2003).

Given these attractive potential yields, many forest companies have since adopted hybrid poplars to increase forest yield on private and public lands. Many reasons have motivated these decisions, depending on regional and local contexts, which include a reduction in allowable cut in native poplar stands (Bureau du forestier en chef 2006), a reduction of operation costs by reducing distance between the resource and industries, and an increase in overall forest productivity.

Because forest companies and private landowners have only recently established hybrid poplar plantations in Québec, real data on the yields of these plantations are scarce. These data are needed to assess the economic benefits of selecting high site quality and improved genotypes (Petrinovic et al. 2009). In what regions or on what type of sites do hybrid poplars offer the best opportunities in terms of yield? This information is essential in order to identify areas of forest management intensification (zones of intensive production) since these zones will eventually have a special status in order to prioritize wood production as a management objective (Québec 2011a).

In this article, we present a brief portrait of hybrid poplar cultivation in Québec, followed by the data available on the yield of hybrid poplar plantations (excluding short-rotation coppice) in different Québec regions and plantation site types (abandoned farmland, clearcut forests, riparian buffers). Based on these data, we discuss what could be the best strategies for poplar cultivation in Québec, with the perspective of implementing a sustainable forest zoning management system. In this paper, the term "hybrid poplar" refers to trees of the genus Populus that have been improved through interspecific crossing. The term "afforested plantations" refers to plantations established on agricultural land, which includes abandoned farmland.

\section{Natural Habitats of Poplar Species Used in the Québec Breeding Program}

The Québec Ministère des Ressources naturelles et de la Faune has been managing a poplar breeding program since 1969 (Riemenschneider et al. 2001). The principal objective of this breeding program is to develop high yielding and disease resistant / tolerant poplar hybrids for the different ecological regions of Québec (Périnet 2007). A list of about 40 recommended clones exists, and all of these clones originate from hybrids of poplar species from the Tacamahaca and Aigeiros sections (Périnet 2007). All of the recommended clones come from five parental species: Populus deltoides, $P$. nigra, P. balsamifera, $P$. trichocarpa and $P$. maximowiczii (Périnet et al. 2008).

Populus deltoides Bartr. ex Marsh. (Eastern cottonwood, Aigeiros section) generally grows in rich humid bottomlands and riparian corridors of North American temperate ecosystems, in pure stands or in association with other bottomland or pioneer species (Farrar 2006). The fastest growth rates for this species are observed on silty and sandy loams of riparian areas that are seasonally flooded, such as those of the Mississippi Valley in the USA (Dickmann and Kuzovkina 2008) and the St. 
Lawrence Valley in Eastern Canada (Farrar 2006). Although it is mostly found in bottomlands, Eastern cottonwood can also colonize upland habitats and disturbed sites where mineral soil is exposed (Dickmann and Kuzovkina 2008).

Populus nigra L. (black poplar, Aigeiros section) is native to Europe, North Africa and western Asia, where it is most often associated with humid sandy soils of river floodplains (Dickmann and Kuzovkina 2008). Upland exposed soil, such as found in wastelands can also be colonized by this aggressive pioneer species (Dickmann and Kuzovkina 2008).

Populus balsamifera L. (balsam poplar, Tacamahaca section) is native to North America, where it is distributed coast to coast at high northern latitudes, reaching $68^{\circ}$ to $69^{\circ} \mathrm{N}$ (Dickmann and Kuzovkina 2008). It is therefore the most cold-hardy poplar in North America. Balsam poplar most often colonizes fluvial valleys and rich and humid bottomlands (Farrar 2006). It also grows on moist or wet soils bordering smaller streams, lakes, wetlands and depressions (Dickmann and Kuzovkina 2008). In those habitats balsam poplar grows in pure stands or in association with other boreal species found on humid soils (e.g., elm [Ulmus spp.], willow [Salix spp.], spruces [Picea spp.], paper birch (Betula papyrifera Marsh.) (Farrar 2006). Balsam poplar can still be found on drier sites and, as a pioneer species, it will invade disturbed sites whether riparian or upland (Dickmann and Kuzovkina 2008).

Populus maximowiczii A. Henry (Japanese poplar, Tacamahaca section) is a pioneer species native to north eastern Asia, where it is found at low to mid elevation (to $2000 \mathrm{~m}$ ) in China, Russia, Korea and Japan (Dickmann and Kuzovkina 2008). Typical habitats of the species are river gravel bars, fluvial plains and low terraces, although it can be found on volcanic ashes on low elevation slopes (Haruki and Tsuyuzaki 2001). Japanese poplar is also very cold-hardy, as it can grow in Siberia (Dickmann and Kuzovkina 2008).

Populus trichocarpa Torr. \& A. Gray (Black cottonwood, Tacamahaca section) grows in Pacific coastal regions at elevations under $1500 \mathrm{~m}$, from Baja California to Alaska, but also inland in northwestern North America (Dickmann and
Kuzovkina 2008). Black cottonwood usually grows on moist alluvial, moraine, and glacial outwash soils in pure stands or with other low-elevation broadleaved species (Dickmann and Kuzovkina 2008). In interior habitats, it can be found up to $2000 \mathrm{~m}$ of elevation along valleys and canyons (Dickmann and Kuzovkina 2008). However, best growth occurs at lowelevation sites influenced by moist Pacific air (Dickmann and Kuzovkina 2008). In those coastal habitats black cottonwood can reach nearly $4 \mathrm{~m}$ in diameter and $60 \mathrm{~m}$ in height, being the largest poplar of all (Dickmann and Kuzovkina 2008).

These five poplar species share an important characteristic: they reach their largest size at low elevation and in rich bottomland, riparian or coastal sites. They can also colonize upland habitats where mineral soil is exposed, but this is not their prime habitat. They also grow in both pure stands and mixed stands with other pioneer species. Therefore, hybrids resulting from the crosses between these five parental species are expected to be fast-growing in the rich bottomland and riparian sites of Québec, but also to be managed as pure stands. It is also well known that hybrid poplars resulting from the crosses of those parental species have very high nutrient requirements for producing high yields (Heilman and Norby 1998).

\section{A Portrait of Hybrid Poplar Cultivation in Québec}

Significant hybrid poplar cultivation began nearly 15 years ago in Québec with forest companies that are now actively managing poplar plantations. Besides forest companies, some small private landowners have also been involved in hybrid poplar cultivation in Québec.

Since 2001, 1 to 1.5 million hybrid poplars have been delivered annually in Québec to establish new plantations, but also to create some agroforestry systems (riparian buffers, shelterbelts, windbreaks, intercropping systems) (Fig. 1). An important decline in hybrid poplar deliveries is obvious since 2007 (Fig. 1). This is not surprising given the economic recession that strongly affected the United States economy at the end of 2007. As with other Canadian provinces, Québec's forest sector is strongly dependant on the US housing market

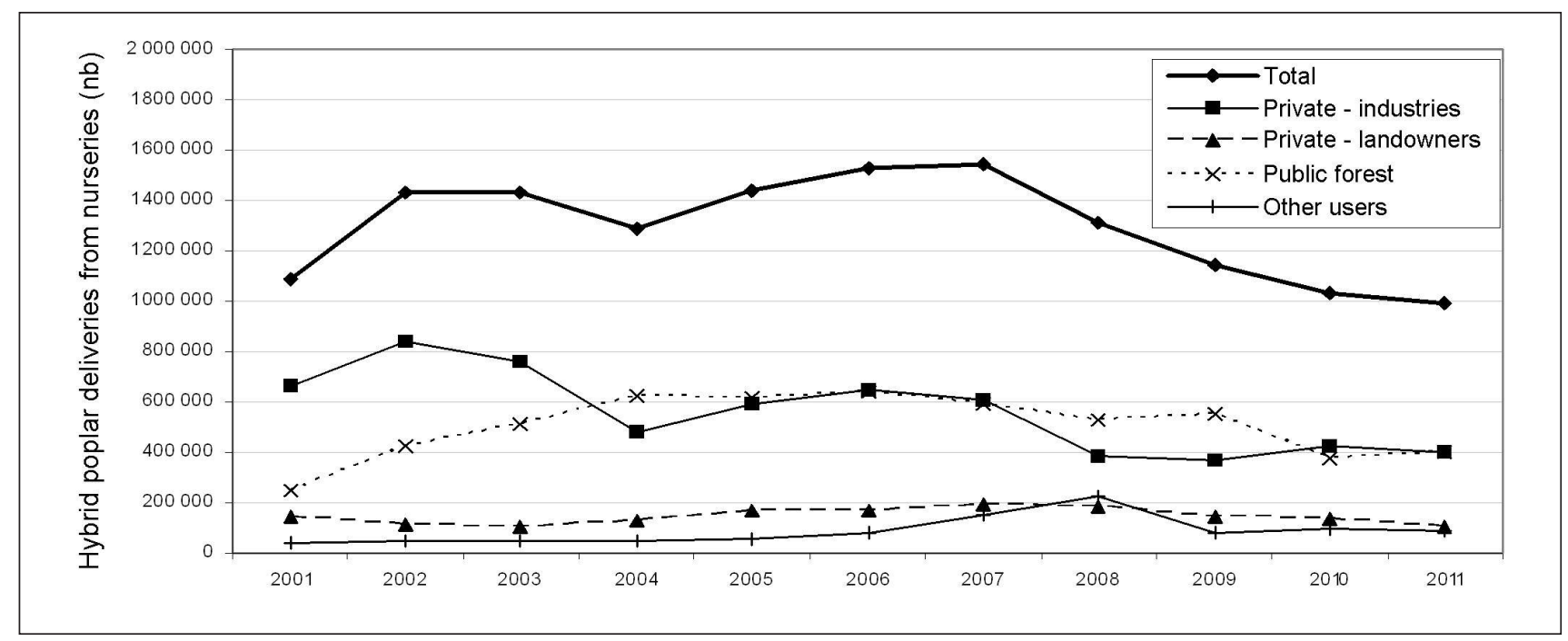

Fig. 1. Evolution of hybrid poplar deliveries from nurseries (nb) to different users: industries that own private land (private - industries), small private landowners (private - landowners), industries operating in public forests (public forest) and all other users including watershed organisations, scientists, agro-environmental consultants (other users). Data obtained from the DPSP, MRNF. 
(Natural Resources Canada 2011). The recent collapse of the US housing market, along with the sharp decline in newsprint sales and the rise of the Canadian dollar (Natural Resources Canada 2011) are all potential explanations for the decreased investment in fast-growing plantations in Québec (Fig. 1).

Another important fact revealed by Fig. 1 is that the vast majority of hybrid poplar plantations are established by the forest industry, whether on private or public land. Hybrid poplar deliveries to small private landowners represent only a very small fraction of total deliveries over the last 10 years.

Overall, approximately 12000 ha of hybrid poplar plantations are managed by industrials, while small private landowners have only planted around 1000 ha (Morissette 2012). Most industrial poplar plantations are established on clearcut forest sites (approx. $11000 \mathrm{ha}$ ) and most plantations owned by small private landowners are established on abandoned farmlands. Compared to other regions of the world, hybrid poplar cultivation in Québec is marginal. For example, China has 4900000 ha of hybrid poplar plantations, India has 1000000 ha and France has 230000 ha (Ball et al. 2005).

Current legislation and regulations are major obstacles to hybrid poplar cultivation development in Québec, particularly on private land in agricultural areas. The establishment of small plantations on private abandoned farmland has been encouraged through financial incentives with programs such as Forêt 2020 (Ménétrier et al. 2005). Nonetheless, in the most intensive agricultural regions of southern Québec, it is very difficult to convert a fertile abandoned farmland into a tree plantation with the financial support of the Québec government. Approvals from both the "Union des producteurs agricoles" (UPA) and the provincial Ministry of Agriculture (MAPAQ) are required in order to receive any financial support and planting material (Marchand and Masse 2007). This is a major obstacle to poplar afforestation in agricultural areas. It is also impossible to get financial support for the conversion of a currently used crop field into a tree plantation.

Furthermore, in some regions of Québec, there is a moratorium on the establishment of pure hybrid polar plantations. This is the case in the Lanaudière region, where only mixed plantations that combine hybrid poplars with broadleaved or coniferous species are financed by the regional forest agency (Agence régionale de mise en valeur des forêts privées de Lanaudière 2011). Compared to pure hybrid poplar plantations, these mixed plantation systems often have additional operational constraints, but also higher establishment and tending costs (J. Moreau, Agence régionale de mise en valeur des forêts privées de Lanaudière, personal communication, 11/09/2011).

In addition, from an economic perspective, land value in Québec's warmest regions and silvicultural costs are among the highest in Canada (Yemshanov and McKenney 2008). Sylvicultural costs of $\$ 3245$ per ha are reported for hybrid poplar afforestation on agricultural land of Québec, while these costs ranged from $\$ 2450$ to $\$ 2825$ per ha for other provinces (Yemshanov and McKenney 2008). Much higher costs are reported for poplar plantations established on abandoned farmland and clearcut forest sites. Poplar plantations established on abandoned farmland in Québec may cost \$ 4600 per ha, while forest site plantations may cost up to $\$ 5500$ per ha (Dancause 2008).

The no-subsidy policy for chemical weed control on private land and the prohibited use of herbicides in public forests can be partly blamed for high costs of tending operations (Fortier and Messier 2006). Multiple disking treatments (sometimes combined with plastic mulching) are therefore needed in the establishment phase of afforested plantations. On clearcut forest sites intensive mechanical site preparation (mounding, disking or scarification) is used, and repeated brushsaw cutting is the main treatment used for competing vegetation control. These silvicultural treatments are mainly financed with public funds.

In short, high-quality sites located on prime agricultural land are very difficult to afforest with hybrid poplars because of these legal and economic constraints (Marchand and Masse 2007, Yemshanov and McKenney 2008). Consequently, in Québec, hybrid poplars have been mostly planted on forest clearcut sites and poor-quality abandoned farmland sites, mainly with poplar clones that have one or both parents from the Tacamahaca (balsam poplar) section (Périnet 2007).

\section{Yield of Hybrid Poplar Plantations and Implications for a Sustainable Forest Zoning Management System}

Based on the available yield data presented in Table 1, three major observations can be made concerning yields of hybrid poplar plantations in Québec:

- Riparian buffers and abandoned farmland plantations have very high yield potentials in warmer climates and on fertile sites.

- Yield variability is very high on both abandoned farmland and riparian buffer sites.

- Yields on forest clearcut sites are generally low.

These observations are based on a small number of studies, in both experimental and operational plantations (Delagrange and Lorenzetti 2008, Ménétrier 2008, Moreau 2008, Labrecque 2009, Duchemin and Ménétrier 2010, Fortier et al. 2010a, Lapointe 2010, Bigué et al. 2011, Bilodeau-Gauthier et al. 2011, Benomar et al. 2012, Truax et al. 2012). Some plantation types or regions are under-represented in Table 1. Additional data need to be collected to provide a clearer portrait. Furthermore, the yield of many young plantations may increase in the future. Still, the general trends that emerge from the available data need to be discussed immediately, especially when a forest zoning management system is being implemented in Québec.

It is important to mention that plantations presented in Table 1 received adequate silvicultural treatments in terms of site preparation and weed control. On abandoned farmland sites, ploughing followed by disking was generally used to prepare sites, while competing vegetation was repressed with herbicide, soil cultivation (disking) or plastic mulching. No site preparation was done in riparian buffers of the study by Fortier et al. (2010a) and a single localized herbicide treatment $\left(1 \mathrm{~m}^{2}\right.$ per tree) was completed during the planting year. On forest clearcut sites, disking, scarification or mounding was used to prepare sites, while mechanical brushsaw cutting was used for vegetation control. Most plantations presented in Table 1 were not fertilized except the ones reported in the study of Delagrange and Lorenzetti (2008).

Finally, concerning clone selection, all clones used in the studies reported in Table 1 were recommended for their superior growth and disease tolerance according to genetic selection trials in different ecological regions of Québec (Périnet et al. 2008). 
Hybrid poplars in sites with rich soils and a warm climate: Where high yield meets high ecosystem services

After only six years, yields as high as $39.6 \mathrm{~m}^{3} \mathrm{ha}^{-1}$ year ${ }^{-1}$ were measured in a riparian agroforestry system (2222 stems per ha) alongside a fertilized pasture at Bromptonville, a site located at low elevation $(140 \mathrm{~m})$ (Fortier et al. 2010a). This indicates that riparian sites, in warm temperate climates, located near fertilized crop fields or pastures of southern Québec have an exceptional potential for hybrid poplar cultivation. In fact, yields measured at Bromptonville are comparable to eucalyptus plantations in tropical countries $\left(40 \mathrm{~m}^{3}\right.$ $\mathrm{ha}^{-1}$ year $^{-1}$ after five to 15 years) (Cossalter and Pye-Smith 2003), even if the growing season is much shorter in southern Québec. Comparable yields have also been reported in other northern temperate locations such as in southern Sweden (31 $\mathrm{m}^{3} \mathrm{ha}^{-1}$ year $^{-1}$ on the best site) (Christersson 2010).

The particular design and landscape position of riparian poplar agroforestry systems may be partly responsible for the high yield observed on four of the five riparian buffer sites (Table 1). In those systems water availability is high during the entire growing season and nutrients are continuously migrating from adjacent fertilized crop fields or pastures through surface runoff and subsurface flow. These streamside plantations also receive periodic nutrients inputs in the form of silt deposition when they are flooded during storm flow events or following snow melt (J. Fortier and B. Truax, personal observation). In addition, high light availability in narrow buffer strips may also be an important factor to sustain high yields considering the shade intolerance of poplars. The relatively high stem density (2222 to 3200 stems per ha) used on riparian buffer sites also partly explains the very high yield achieved in a short time period (five to six years) (Table 1).

Very high yields were also observed on the bottomland sites of Bedford (22.4 $\mathrm{m}^{3} \mathrm{ha}^{-1}$ year-1 at eight years), in the Montérégie region, and of Lavaltrie $\left(16.4 \mathrm{~m}^{3} \mathrm{ha}^{-1}\right.$ year ${ }^{-1}$ at six years), in the Lanaudière region, despite their intermediate stem densities (833 stems per ha) and young age (Moreau 2008, Truax et al. 2012) (Table 1). Both of these plantations were established on recently abandoned farmland, located in the St. Lawrence Valley, which is dominated by intensive agricultural land use because of its favourable climate and high soil fertility (Robitaille and Saucier 1998). The highest yields obtained in southern Québec are comparable to those obtained on high-quality agricultural sites of southern Ontario, were the best clones produced $29 \mathrm{~m}^{3} \mathrm{ha}^{-1}$ year ${ }^{-1}$ after 12 years (Zsuffa et al. 1977).

On agricultural sites, the very high yield variability of poplar plantations is also evident in Table 1. For example, the poplar buffer at Bromptonville was 36 times more productive than the plantation at Stornoway (450 m elevation), which was located on a low-fertility abandoned farmland site (Truax et al. 2012). Poplar growth is highly sensitive to both soil fertility and climate (Tabbush and Beaton 1998, Stanturf et al. 2001, Coleman et al. 2006). In southern Québec, three factors were highly correlated to yield: (1) $\mathrm{NO}_{3}$ supply rate in riparian soils was positively correlated to yield $\left(R^{2}=0.58\right)$ (Fortier et al. 2010a); (2) elevation was negatively correlated to yield ( $R^{2}=0.40$ to 0.77 , depending on the clone) (Truax et al. 2012), and (3) soil P availability was positively correlated to yield ( $R^{2}=0.64$ to 0.87 , depending on the clone) (Truax et al. 2012) on abandoned farmland soils. Based on these indica- tors, but also using well known site characteristics for optimal hybrid poplar cultivation (e.g., soil depth $>1 \mathrm{~m}$, loamy soil texture, good drainage, $\mathrm{pH} 5$ to 7.5 , high growing degree days) (Boysen and Strobl 1991, Stanturf et al. 2001), site suitability maps could be easily created. These types of maps already exist for the Canadian Prairies (Schroeder et al. 2003, Joss et al. 2008) and are highly needed in Québec. Already-existing maps of agricultural potential and soil surveys (Cann and Lajoie 1943, MAPAQ 2005) could easily be used has a starting point.

In addition, the results of Truax et al. (2012) clearly show that all hybrid types studied $(\mathrm{D} \times \mathrm{N}, \mathrm{T} \times \mathrm{D}, \mathrm{N} \times \mathrm{M}, \mathrm{M} \times \mathrm{B}$, $\mathrm{DN} \times \mathrm{M}$ ) are very sensitive to a decrease in soil fertility, which contradicts the notion that hybrid poplars related to the Tacamahaca (balsam poplar) section are less sensitive to lower soil fertility (Riemenschneider et al. 2001, Périnet 2007). However, P. maximowiczii hybrids are clearly better adapted to cooler climates, particularly the $\mathrm{M} \times \mathrm{B}$ hybrid, which has both of its parental species in the Tacamahaca section (Truax et al. 2012). Therefore, interesting yields were observed with $\mathrm{N} \times \mathrm{M}, \mathrm{M} \times \mathrm{B}$ and $\mathrm{DN} \times \mathrm{M}$ hybrids, on cooler but nevertheless fertile sites of southern Québec, such as at La Patrie (440 m elevation) (Truax et al. 2012) (Table 1). However, on boreal sites with inadequate soil texture (heavy clay) or fertility, and short growing season, $\mathrm{M} \times \mathrm{B}$ hybrids were not very productive (Bilodeau-Gauthier et al. 2011, Benomar et al. 2012) (Table 1). Thus, in the boreal zone, even when very high stem density (10 000 stems per ha) is used, marginal yields $\left(3.4 \mathrm{~m}^{3} \mathrm{ha}^{-1}\right.$ year $\left.{ }^{-1}\right)$ are still observed after six years (Benomar et al. 2012).

As is the case for the five parental species used in the Québec poplar breeding program, all hybrids recently studied reached their largest size and yield on low-elevation and rich bottomland sites, or riparian sites (Fortier et al. 2010a, Truax et al. 2012). Consequently, clone selection alone cannot compensate for inadequate site selection and only moderate- to high-fertility sites should be afforested with poplars, and lowfertility sites should be avoided altogether. Although many abandoned farmland sites exist in different Québec regions (Vouligny and Gariepy 2008), it may not be the majority that will satisfy high poplar nutritional requirements and produce high yields. One good reason for this is that poor soils and/or poor climate have often been the reasons for abandonment.

Besides high yields, poplar afforestation and agroforestry in intensive agriculture landscapes could produce a wide array of ecosystem services and directly contribute to biodiversity conservation (Brockerhoff et al. 2008, Chazdon 2008), while creating local economic opportunities (Rockwood et al. 2004). Ecosystem services and goods (Costanza et al. 1998) provided by poplar afforestation on agricultural land include: climate regulation trough $\mathrm{C}$ sequestration in soil and biomass (Zabek and Prescott 2006, Fang et al. 2007, Arevalo et al. 2011); flood control (Perry et al. 2001); wind protection (Isebrands and Karnosky 2001); erosion control (Updegraff et al. 2004, Zaimes et al. 2004); soil formation (Tufekcioglu et al. 2001, Mao et al. 2010); long-term nutrient storage (Tufekcioglu et al. 2003, Kelly et al. 2007, Fortier et al. 2010b); increased $\mathrm{N}$ immobilisation in riparian soils (Schimel et al. 1998, Schweitzer et al. 2008); groundwater $\mathrm{N}$ retention (Haycock and Pinay 1993); bioremediation of soil containing pesticides (Burken and Schnoor 1997, Jordahl et 
al. 1997); shade-intolerant exotic plant control (Fortier et al. 2011) and refugia for local biodiversity (Christian 1997, Lust et al. 2001, Weih et al. 2003, Gardiner et al. 2004, Archaux and Martin 2009, Boothroyd-Roberts 2011, Fortier et al. 2011); production of livestock feed and nutritional supplements (McWilliam et al. 2004); bioenergy, wood, fibre, ethanol fuel and fertilizer production (Balatinecz et al. 2001, Licht and Isebrands 2005, Singh and Sharma 2007, González-García et al. 2010); production of bioproducts that have applications in medicine, health, food and cosmetics (Popova et al. 2007, Vardar-Ünlü et al. 2008), and, finally, creation of aesthetic structures that can be used for outdoor activities (Le Floch 2002). Additional details concerning these ecosystem services are given in Table 2.

In oversimplified landscapes, such as those dominated by intensive agriculture, the local allocation of habitat is far more important than in complex landscapes for increasing both biodiversity and ecosystem services (Tscharntke et al. 2005). Increasing the structural complexity of these oversimplified landscapes with poplar plantation and agroforestry may compensate for high farming intensity at a local scale (Tscharntke et al. 2005). In the St. Lawrence Valley, where intensive agriculture is mainly concentrated, eight Regional County Municipalities (MRC) have less than 20\% of their forest cover remaining (Bélanger and Grenier 2002), which is far below the $30 \%$ threshold that is accepted as the minimal forest cover needed before fragmentation effects begin to occur, and impinge on biodiversity at the landscape level (Andrén 1994). Bélanger and Grenier (2002) also observed that in southern Québec forest habitat fragmentation increased along a gradient from traditional dairy farming to highly intensive cash crop agriculture.

Therefore, we consider that poplar afforestation and agroforestry should be a priority in the oversimplified landscapes of the St. Lawrence Valley, because poplars have the potential to create semi-natural forest habitats within 10 years. These poplar systems would radically increase structural complexity, which would increase local diversity, agroecosystem resilience and ecosystem services (Tscharntke et al. 2005, Chazdon 2008) (Table 2).

Poplar yields are also expected to be maximal on these highly fertile and warm-climate sites. It is well known that many cropland soils of the St. Lawrence Valley are phosphorus-saturated because of over-fertilization (MAPAQ 2005, CAAAQ 2007). The province of Québec should take advantage of this problem by establishing poplar agroforestry systems and small-scale plantations in these areas in order to phytoremediate P-saturated soils (Licht and Isebrands 2005). P-saturated soils would be ideal for poplar cultivation because most hybrid types responded strongly to $\mathrm{P}$ availability in agricultural soils of southern Québec (Truax et al. 2012).

\footnotetext{
Hybrid poplar plantations on clearcut forest sites: An unproductive silvicultural approach?

Hopefully, hybrid poplar plantation yields on clearcut forest sites that are presented here represent the exception rather than the rule, because yields are particularly low $\left(0.5-1.4 \mathrm{~m}^{3}\right.$ $\mathrm{ha}^{-1}$ year $^{-1}$ ) (Table 1). All hybrid poplar plantations on clearcut sites in Table 1 have not yet reached the yield of natural trembling aspen (P. tremuloides) regeneration, which has a mean yield of $3.4 \mathrm{~m}^{3} \mathrm{ha}^{-1}$ year $^{-1}$ in Québec (Dancause 2008).
}

Even considering all possible caveats, these low yield data should raise serious concerns because $80 \%$ of hybrid poplar plantations in Québec are established on clearcut forest sites. These plantations, although young, seem very far from being considered "short rotation woody crops" (SRWC), since a realistic mean yield of SRWCs generally falls within $10 \mathrm{~m}^{3} \mathrm{ha}^{-}$ ${ }^{1}$ year ${ }^{-1}$ to $30 \mathrm{~m}^{3} \mathrm{ha}^{-1}$ year $^{-1}$, depending on clone, site quality, region and cultivation methods (Dickmann 2006).

The low yield trend of forest sites for hybrid poplars has long been documented in other countries and should have represented a clear warning signal to Québec forest managers. On a clearcut forest site in Maine, USA (soil pH 4.9), Czapowskyj and Stafford (1993) reported stem wood biomass yields of about $28 \mathrm{t} \mathrm{ha}^{-1}$ after 10 years in a closely spaced plantation (2500 stems per ha) with clones from the Tacamahaca section ( $\mathrm{M} \times \mathrm{T}$ hybrids). This represents a volume yield of approximately $5 \mathrm{~m}^{3} \mathrm{ha}^{-1}$ year ${ }^{-1}$, which is low considering the treatments the plantation had received: soil scarification for site preparation; brush-cutting over three years for competing vegetation control; $4480 \mathrm{~kg} \mathrm{ha}^{-1}$ of lime; $448 \mathrm{~kg} \mathrm{ha}^{-1}$ of $\mathrm{N}, 112$ $\mathrm{kg} \mathrm{ha}^{-1}$ of $\mathrm{P}$ and $112 \mathrm{~kg} \mathrm{ha}^{-1}$ of $\mathrm{K}$. According to the authors, the clearcut site yield was far from yields obtained on nearby agricultural sites, and additional inputs of lime and fertilizer would have been needed to close the yield gap between the two plantation types (Czapowskyj and Safford 1993). Alternatively, they suggest that native hardwood species should be considered for intensive silviculture on clearcut sites since naturally regenerated unmanaged hardwood stands in Maine and New Hampshire produce yields similar to that of the best treatment in hybrid poplar plantations on forest clearcut sites (Young et al. 1979, Martin and Hornbeck 1989).

Another important study comes from France, where hybrid poplars have also been tested on forest soils outside agricultural valleys. After nine years, in a closely spaced plantation (3200 stems per ha), Gelhaye et al. (1997) conclude that hybrid poplar plantations on forest sites had a marginal yield $\left(<5 \mathrm{t} \mathrm{ha}^{-1}\right.$ year $\left.{ }^{-1}\right)$, even with the most intensive fertilization treatment. They suggest that hybrid poplar coppice stands established on forest clearcut sites had no future for sustaining industrial development in France.

More recently, similar conclusions were reported for hybrid poplars after six years of growth on a clearcut site in Maine, USA (Nelson et al. 2011). These authors measured yields that were substantially lower than those reported from studies on abandoned farmlands of the region, mainly because of the harsher soil conditions of the forest site. They argued that the high proportion of similar soil conditions on forest sites of the eastern Maine region would limit large-scale establishment of poplar plantations on forest clearcut sites.

We feel that most forest sites of Québec cannot fulfill hybrid poplar nutritional requirements. For example, Bilodeau-Gauthier et al. (2011) showed that poplar DBH growth can be enhanced on boreal forest sites by using very intensive and costly site preparation methods such as mechanical mounding. However, based on our calculations this resulted in a yield under $1 \mathrm{~m}^{3} \mathrm{ha}^{-1}$ year-1 in the best treatment (mechanical mounding plus brush saw removal of competing vegetation) after five years (Table 1). This is not unexpected, considering that the plantation soil had a mean $\mathrm{pH}$ of 4.13 .

Hybrid poplars generally require a soil $\mathrm{pH}$ between 5 and 7.5 for optimal growth (Stanturf et al. 2001). Outside this $\mathrm{pH}$ 
Table 2. Ecosystem services (including goods) that may be provided or restored following poplar afforestation of farmland and abandoned farmland in temperate ecosystems

\section{Ecosystem services Description}

Carbon sequestration Afforestation of agricultural land (including abandoned farmland) with hybrid poplar increases C sequestration in biomass and in soils, depending on rotation length (Zabek and Prescott 2006, Fang et al. 2007, Arevalo et al. 2011).

Disturbance and water regulation By having a similar water yield to that of natural hardwood forests, poplar plantations in agricultural landscapes can reduce peak flows, storm flows, snowmelt runoff and spring flooding in temperate regions (Perry et al. 2001). Poplar agroforestry systems (timberbelt and shelterbelt) can protect farm buildings, orchards and livestock from cold winter wind, while decreasing moisture loss during summer (Isebrands and Karnosky 2001).

Erosion control and A $30 \%$ cropland conversion to hybrid poplar plantations can reduce sediment export to streams by $28 \%$. This could sediment retention reduce maintenance of ditches and culverts (Updegraff et al. 2004).

Riparian forest buffers composed of hybrid poplars can reduce stream bank erosion rate compared to row crops and grazed pastures (Zaimes et al. 2004).

Hybrid poplar agroforestry systems (timberbelt and shelterbelt) can reduce soil loss through wind erosion (Isebrands and Karnosky 2001).

Soil formation

Hybrid poplar afforestation on marginal agricultural land can contribute to soil C stock restoration (Mao et al. 2010).

Soil respiration and biological activity can be enhanced by hybrid poplar buffer plantations (Tufekcioglu et al. 2001).

Nutrient cycling and Riparian afforestation with poplars can increase long-term $\mathrm{N}$ and $\mathrm{P}$ storage in above- and below-ground biomass, pollution control compared to herbaceous vegetation (Tufekcioglu et al. 2004, Kelly et al. 2007, Fortier et al. 2010b).

Tannins and other phenolic compounds contained in poplar leaves and roots can increase $\mathrm{N}$ immobilisation in riparian soils (Schimel et al. 1998, Schweitzer et al. 2008), and eventually reduce N loss to stream water.

Poplar-vegetated riparian zones may increase groundwater $\mathrm{N}$ retention during winter months compared to grassvegetated riparian zones (Haycock and Pinay 1993).

A 30\% cropland conversion to hybrid poplar plantations can reduce $\mathrm{N}$ loads to streams by $15 \%$ (Updegraff et al. 2004).

Poplar rhizosphere enhances viability of beneficial micro-organisms important for natural bioremediation processes (Jordahl et al. 1997).

Hybrid poplar trees can uptake, hydrolyze, and dealkylate pesticides, such as atrazine, to less toxic metabolites (Burken and Schnoor 1997).

Biological control Hybrid poplar afforestation in riparian areas can create an unfavourable habitat for shade-intolerant exotic plant species without affecting native species (Fortier et al. 2011).

Refugia When poplars are not planted at the expense of areas of high conservation value, they may increase overall diversity of bird communities within farmland habitats (Archaux and Martin 2009).

Poplar plantations provide equivalent or greater habitat for native birds and mammals, compared to croplands (Christian et al. 1997).

Poplar afforestation can contribute to forest restoration by providing habitats for shade-tolerant hardwoods and coniferous species (Lust et al. 2001, Boothroyd-Roberts 2011).

Hybrid poplar plantation can create favourable understory conditions for planting high-value non-timber forest species (wild ginseng, bloodroot, white trillium) instead of harvesting from wild populations (Boothroyd-Roberts 2011). Valuable hardwoods such as oaks can also be underplanted in poplar plantations (Gardiner et al. 2004). Hybrid poplar afforestation increases plant diversity in agriculture-dominated landscapes (Weih et al. 2003).

Livestock production Poplar branches and foliage can be harvested, creating an inexpensive feed for livestock in times of drought (McWilliam et al. 2004).

The use of poplar cuttings as supplements in the diet of ewes can increase reproduction rate (McWilliam et al. 2004).

Raw materials and fuel Poplar biomass (round wood, chips or pellets) can be used for heating farm buildings, greenhouses, institutions, industries, etc. (Licht and Isebrands 2005).

Poplar wood and fibre is currently used for pulp and paper products and solid wood products (OSB, plywood, veneer) (Balatinecz et al. 2001).

Poplar leaf litter can be used as an organic fertiliser (Singh and Sharma 2007).

Poplar cellulose may be used for the production of ethanol fuel and other bio-products (González-García et al. 2010).

Genetic resources Propolis production from planted poplars may become a major economic activity. Because of its antimicrobial activity and antioxidant proprieties, poplar propolis has applications in bio-cosmetics, health food and medicine (Popova et al. 2007). Poplar-type propolis and poplar bud exudates inhibit most clinically important microorganisms (Vardar-Ünlü et al. 2008).

Recreation and culture Floodplain poplar plantations may be seen as an aesthetic and dynamic land use, while offering recreational opportunities (wildlife watching, walking) (Le Floch 2002). 
range, essential nutrients that are highly correlated to the yield of different clone parentages ( $\mathrm{P}, \mathrm{N}$ and $\mathrm{Ca}$ ) (Fortier et al. 2010a, Truax et al. 2012) become much less available. As shown by Timmer (1985), acidifying the soil to $\mathrm{pH} 4.1$ greatly depresses hybrid poplar growth and foliar uptake of essential nutrients. Low poplar growth has also been observed on acidic forest sites of southern Québec (Gould and St-Hilairede-Dorset in Table 1) (Labrecque 2009).

Even when large quantities of lime (2000-4000 $\left.\mathrm{kg} \mathrm{ha}^{-1}\right)$ are added to forest soils of southern Québec ( $\mathrm{pH}$ ranging from 4.7 to 5), it seems that hybrid poplars remained in a state of nutritional imbalance (Bona et al. 2008). Lime addition may increase foliar Ca concentrations, but not necessarily leaf $\mathrm{N}$ and $\mathrm{P}$ concentrations (Bona et al. 2008). With foliar $\mathrm{N}$ and $\mathrm{P}$ concentrations ranging between $1.18 \%$ and $1.21 \%$ and $0.11 \%$ to $0.18 \%$, respectively, after lime addition (Bona et al. 2008), these forest-grown hybrid poplars were far from meeting poplar nutritional requirements: foliar $\mathrm{N}$ between $2.5 \%$ and $3 \%$ (depending on clone parentage) and foliar $\mathrm{P}$ around 0.33\% (Hanson 1994).

Given all of these facts, we have good reason to be sceptical when Bilodeau-Gauthier et al. (2011) suggest that even in the harsh conditions of the boreal forest, the production of a large volume of wood is possible within 20 years with hybrid poplars. As we have shown, the unfavourable soil conditions combined with the harsher climate of most forest sites will be inappropriate to fulfill the high nutritional needs, even of the most cold-hardy hybrid poplar clones. Fertilization may be used on forest sites or on low-quality abandoned farmland sites, but it will increase already high plantation costs, as well as environmental impacts (Lteif et al. 2007), with no guaranty of a high yield increase (DesRochers et al. 2006, Guillemette and DesRochers 2008, Bilodeau-Gauthier et al. 2011).

Besides the low yield of hybrid poplar plantations on forest sites, other concerns exist. Poplar growth tends to be very heterogeneous on forest sites (J. Fortier, personal observation), which greatly decreases the uniformity of log size at harvest. Also, higher-quality forests sites may not be easily and precisely located with available GIS technology (Pinno et al. 2009, Bigué et al. 2011), which further jeopardizes the success of hybrid poplar cultivation on forest sites in Québec.

In addition, $P$. maximowiczii hybrids are mainly planted in southern and northern forest sites of Québec because they seem more adapted than other hybrid types (Périnet 2007). However, the results of Truax et al. (2012) are clear: the yields of $\mathrm{N} \times \mathrm{M}, \mathrm{DN} \times \mathrm{M}$ and $\mathrm{M} \times \mathrm{B}$ hybrids are highly correlated to soil $\mathrm{P}$ availability, and to elevation to a lesser extent. Therefore, acidic soils of the boreal shield ecozone are likely to be too limited in $\mathrm{P}$ and in growing degree days to sustain high yields.

Balsam poplar clones $(\mathrm{M} \times \mathrm{B}$ hybrids) tend to have lower wood density than $\mathrm{T} \times \mathrm{D}$ and $\mathrm{D} \times \mathrm{N}$ hybrids (Pliura et al. 2007), which are mainly planted on agricultural soils. The wide crown and forking habit of some balsam poplar clones, combined with their lower stem wood density, can lead to crown breakage (J. Fortier and B. Truax personal observation). Therefore, for some clones related to the Tacamahaca section, wind, snow and ice damage might become a problem over the years, particularly if the frequency and severity of extreme climate events increases with ongoing global changes. This may explain why $P$. deltoides and $\mathrm{D} \times \mathrm{N}$ hybrids are now favoured over balsam poplar hybrids for shelterbelts in northern North American Prairies (Dickmann and Kuzovkina 2008). On low-quality sites, longer rotation length will also be needed to produce harvestable trees. This will increase the probability of occurrence of hazardous climatic events and pest outbreaks in poplar plantations.

Finally, it is important to highlight that forest conversion to "exotic" poplar plantations has numerous negative environmental impacts. In general, a net loss of soil $\mathrm{C}$ is associated with site preparation, and this $\mathrm{Closs}$ increases with the degree of disturbance (Schmidt et al. 1996, Jandl et al. 2007). Consequently, the intensive site preparation method (mechanical mounding and scarification) used on clearcut forest sites prior to hybrid poplar establishment can lead to significant soil C losses. Liming, another treatment used on acidic forest soils (Czapowskyj and Safford 1993, Bona et al. 2008), generally causes a net loss of soil $\mathrm{C}$ in both temperate and boreal forest ecosystems due to increased microbial activity (Jandl et al. 2007).

In addition, conversion of natural forests to plantations is detrimental to biodiversity, particularly when short-rotation exotic plantations replace forest complexity and diversity (Hartley 2002, Brockerhoff et al. 2008). As reviewed by Thompson et al. (2003), this type of conversion always results in large impacts on wildlife communities. This contrasts sharply with afforestation of agricultural, long-deforested landscapes, which is known to assist conservation by providing complementary forest habitat, buffering edge effects, and increasing connectivity (Brockerhoff et al. 2008).

It is possible that the richest forest sites may need to be converted to poplar plantation to achieve economically viable yields. However, this strategy may worsen the adverse effects of forest conversion to poplar plantations since site fertility is generally positively correlated to animal biodiversity in forest ecosystems (Thompson et al. 2003). This potential problem will not occur in Québec agricultural landscapes since most fertile sites are biodiversity-poor because of agricultural activities. Finally, for some certification organisations such as the Forestry Stewardship Council (FSC), important limitations exist concerning forest conversion to exotic plantations (FSC 2004).

Ultimately, to really appreciate the net gain of productivity of plantation establishment following forest conversion, it is important to subtract the yield of the natural forest that has been replaced from the yield of the new plantations. With that in mind, it seems that forest clearcut site poplar plantations will not produce important net wood volume increases.

\section{Implications for a sustainable forest zoning system}

Recently, forest zoning has been proposed for application at the regional or management unit scale only in the public forests of Québec, with no possible application in the southern belt of Québec where urban development, farmland and privately owned forests dominate the landscape (Messier et al. 2009, Hartmann et al. 2010). However, we feel that applying forest zoning at a regional or management unit scale is based on the erroneous premise that all forested regions or management units of Québec possess sufficient areas of productive sites to create a functional intensive management zone that will compensate, with higher yields, the productivity losses needed to accommodate ecosystem management and conservation. 
In some forest ecozones (boreal shield, boreal clay belt), low soil fertility, inappropriate soil texture and/or unfavourable climate make it difficult to achieve high-yield poplar plantations (Bigué et al. 2011, Bilodeau-Gauthier et al. 2011, Benomar et al. 2012) (Table 1). Consequently, in those ecozones, much larger areas under intensive management will be required to achieve the same wood volume per area that could be produced in southern agricultural zones (riparian buffers, abandoned farmland, and farmland).

The afforestation and forest conversion scenarios presented in Table 3 illustrate the effect of plantation yield on land area dedicated to plantation forestry under a forest zoning management approach. In Table 3, the afforestation scenario is based on $5 \%$ poplar afforestation on the total cultivated land area of Québec (1 930000 ha) (Statistique Canada 2008), 25\% poplar afforestation on the total abandoned farmland area in southern Québec (85 000 ha) (Vouligny and Gariepy 2008) and the installation of 4.5-mwide poplar buffers on both sides of $25 \%$ of the total length of degraded streams (including large ditches) in agricultural areas $(40000 \mathrm{~km})$ (Beaulieu 2001). In this scenario, an estimated 2 million $\mathrm{m}^{3}$ year $^{-1}$ could be produced with hybrid poplar plantations and agroforestry, on only 126750 ha of agricultural land. In counterpart, it would potentially require between 416250 ha and 594642 ha to produce the same wood volume with hybrid poplar plantations established on clearcut forest sites (Table 3).

Because the main objective of the zoning approach is to minimize the negative environmental impacts of forestry while maintain timber supply (Côté et al. 2010), it seems paradoxical to convert large areas of natural forests, at the expense of biodiversity and $\mathrm{C}$ sequestration, into low-yielding plantations to make the forest zoning concept operational in northern forest ecosystems. Hybrid poplar cultivation is possible on colder sites, but those should be located in agricultural landscapes such as in southern and central Sweden (Christersson
2008). On those sites, the potential of hybrid trembling aspens (section Populus, formerly Leuce) need to be tested given their very high yield in Sweden (Christersson 2010).

Lower yields in forest site poplar plantations will also result in much longer rotations, which will greatly increase the time period in which a poplar plantation is vulnerable to insect pests and physical damage, but also to disease, which is "coping with the inevitable" (Mattson et al. 2001). More than 10 years ago doubts were raised about the feasibility of intensive forestry plantations on public lands in northern Ontario (Lautenschlager 2000). We share these doubts, but we are also concerned about the general economic profitability of hybrid poplar systems outside of moderate- to high-fertility agricultural zones.

Applying forest zoning at the provincial scale would be a more effective management option than a regional application of the concept. By locating poplar plantations in the most intensive farming landscapes of southern Québec (e.g., Bromptonville, Bedford and Lavaltrie sites in Table 1), large wood volumes and many ecosystem services could be provided simultaneously (Table 2 ). With high yields generated outside of forests in southern Québec, large northern areas could therefore be dedicated to conservation and ecosystem management forestry. This strategy would avoid the negative impacts on climate and biodiversity that are associated with natural forest conversion to plantations.

New afforested plantations and agroforestry systems should ideally be designed and managed to increase landscape connectivity, agroecosystem resilience and economic profitability to farmers (Licht and Isebrands 2005, Brockerhoff et al. 2008). However, although poplar systems have been considered for many years as sustainable components of agroecosystems (Licht 1992), many political, economic and social hurdles remain in the Québec agricultural context.

First, hybrid poplars managed on longer rotations (five to 20 years) need to be considered as a crop in Québec. For

Table 3. Wood production and plantation costs obtained from a realistic hybrid poplar afforestation scenario in agricultural areas of Québec province. For comparison purposes, the land area required of clearcut site plantations that would be needed to achieve equivalent wood production were calculated.

\begin{tabular}{|c|c|c|c|c|c|c|}
\hline Plantation sites & $\begin{array}{l}\text { Total land } \\
\text { area (ha) } \\
\text { or stream } \\
\text { length (km) }\end{array}$ & $\begin{array}{l}\text { Afforestation } \\
\text { scenario }\end{array}$ & $\begin{array}{l}\text { Plantation } \\
\text { land area (ha) }\end{array}$ & $\begin{array}{l}\text { Mean yield } \\
\left(\mathrm{m}^{3} \mathrm{ha}^{-1} \text { year }^{-1}\right)\end{array}$ & $\begin{array}{l}\text { Wood } \\
\text { production } \\
\left(\mathrm{m}^{3} \text { year }^{-1}\right)\end{array}$ & $\begin{array}{l}\text { Plantation } \\
\text { costs }\left(\$ \text { ha }^{-1}\right) \mathrm{g}\end{array}$ \\
\hline Cultivated land & $1930000 \mathrm{ha}^{\mathrm{a}}$ & $5 \%$ & 96500 & 17.5 & 1688750 & 3245 \\
\hline Abandoned farmland & $85000 \mathrm{ha}^{\mathrm{b}}$ & $25 \%$ & 21250 & 10 & 212500 & 4600 \\
\hline Degraded small streams & $40000 \mathrm{~km}^{\mathrm{c}}$ & $25 \% \mathrm{~d}$ & 9000 & 20 & 180000 & 3245 \\
\hline Total agricultural land & - & - & 126750 & - & 2081250 & - \\
\hline Good-quality clearcut forest & - & - & 416250 & $5^{\mathrm{e}}$ & 2081250 & 5500 \\
\hline Average-quality clearcut forest & - & - & 594642 & $3.5^{\mathrm{f}}$ & 2081250 & 5500 \\
\hline \multicolumn{7}{|c|}{ aArea of cultivated land obtained from Statistique Canada (2008). } \\
\hline \multicolumn{7}{|c|}{ bArea of abandoned farmland of southern Québec calculated from the data of Vouligny and Gariepy (2008). } \\
\hline \multirow{2}{*}{\multicolumn{7}{|c|}{$\begin{array}{l}\text { cDegraded streams include } 30000 \mathrm{~km} \text { of degraded streams in agricultural areas and } 10000 \mathrm{~km} \text { of large drainage ditches (Beaulieu } 2001 \text { ). } \\
\text { dThis afforestation scenario is based on the establishment of } 4.5 \text {-m-wide riparian buffers, as described in Fortier et al. (2010a), on both stream banks of } 25 \% \text { of } 40000 \mathrm{~km} \text { of } \\
\text { degraded streams. }\end{array}$}} \\
\hline & & & & & & \\
\hline \multicolumn{7}{|c|}{$\begin{array}{l}{ }^{e} \text { Mean yield of clearcut plantation is based on an average yield of } 7.5 \mathrm{~m}^{3} \mathrm{ha}^{-1} \mathrm{year}^{-1} \text { from which we subtracted the yield of natural broadleaved forests }\left(2.5 \mathrm{~m}^{3} \text { ha }{ }^{-1} \mathrm{yr}^{-1}\right) \text { that have been } \\
\text { removed through forest conversion to plantations. }\end{array}$} \\
\hline \multicolumn{7}{|c|}{$\begin{array}{l}{ }^{\mathrm{f}} \text { Mean yield of clearcut plantation is based on an average yield of } 5 \mathrm{~m}^{3} \mathrm{ha}^{-1} \text { year }^{-1} \text { from which we subtracted the yield of natural broadleaved forests }\left(1.5 \mathrm{~m}^{3} \text { ha }{ }^{-1} \text { year-1) that have }\right. \\
\text { been removed through forest conversion to plantations. }\end{array}$} \\
\hline
\end{tabular}


example, in British Columbia hybrid poplars are considered a speciality woody crop, whether the objective is to produce pulp on short rotations, solid wood products on longer rotations, or to improve environmental quality (riparian buffer, reclaimed water use, bioengineering) (BC Ministry of Agriculture Food and Fisheries 2004). By giving hybrid poplars a "crop status", farmers will have the opportunity to obtain planting stock and subsidies for purposes other than biomass, which is currently impossible on Québec prime agricultural land. With such a status, cost-efficient weed control tools such as herbicides will be permitted as they are in short-rotation coppice systems.

In temperate ecosystems, riparian forests are keystone watershed elements for both biodiversity and water quality protection (Gregory et al. 1991, Naiman et al. 2005, Dosskey et al. 2010). Afforestation projects in riparian zones would help in recovering some ecological functions and ecosystem services associated with natural riparian forests (Table 2), without causing important increases in $\mathrm{N}_{2} \mathrm{O}$ emissions at the regional level because of increased denitrification (Lal et al. 2011). Financial incentives should encourage the establishment of wide woody riparian buffers (10 m wide or more) given their multi-functionality, but also their very high yields (Schultz et al. 2004; Fortier et al. 2010a,b, 2011). These wide buffers are particularly needed on sloping, fine-textured soils and alley cropping sites, to obtain satisfactory non-point source pollution abatement (Dosskey et al. 2008). At the moment, regulations only restrict some agricultural activities (fertilization, pesticide application) within a $1-\mathrm{m}$ - to $3-\mathrm{m}$ wide streamside zone, depending on stream width (Québec $2011 b, c)$, which on many sites is clearly insufficient to improve water quality (Dosskey et al. 2008). Financial incentives are particularly needed to overcome the costs of poplar buffer installation and maintenance and, more importantly, the loss of cultivated land revenue. This is a major issue that can be resolved by giving crop insurance to any individual who converts part of a crop field near a stream edge into a hybrid poplar riparian buffer.

Also, municipal regulations concerning tree harvesting in riparian zones need to be adjusted to allow the harvest of poplars that were especially planted for wood production and nutrient storage/removal in agroecosystems. Trees, and particularly poplars, are fast-growing nutrient sinks in agroecosystems (Kelly et al. 2007, Fortier et al. 2010b). Harvest of these trees results in a large nutrient ( $\mathrm{N}$ and $\mathrm{P}$ ) exportations from local agroecosystems (Fortier et al. 2010b). A phosphorus credit program that pays for every $\mathrm{kg}$ of $\mathrm{P}$ exported from P-saturated areas might encourage farmers to adopt best management practices and reduce $\mathrm{P}$ transport into streams. Cyanobacterial blooms in many lakes and rivers of agricultural watersheds of southern Québec have been reported (Francoeur 2006), a phenomenon closely linked to the transport of surplus $\mathrm{P}$ of agricultural origin and its contamination of streams, rivers and lakes (Giani et al. 2005). Furthermore, since water quality and aquatic ecosystem quality are correlated to forest cover at both watershed and riparian levels (Allan 2004, Sweeney et al. 2004, Stephenson and Morin 2009), increasing global forest cover with both upland and riparian hybrid poplar plantation systems in landscapes with low forest cover may also improve water quality and aquatic habitats.
Additionally, production of biomass with hybrid poplar agroforestry in the riparian zone of fertilized farmland is likely to be a more sustainable alternative to the harvesting of residual natural forest biomass (Fortier et al. 2010a), which may decrease long-term forest site fertility and carbon sequestration (Hendrickson et al. 1989, Johnson and Curtis 2001). This approach would take advantage of the nutrient surplus that already exists in many agricultural areas of southern Québec (MAPAQ 2005, CAAAQ 2007) and it would produce woody biomass close to several end users (e.g., farm buildings, greenhouses, houses, institutions, industries, US market).

In highly fragmented landscapes such as those of the St. Lawrence Valley (Bélanger and Grenier 2002), plantations, riparian buffers, corridors and shelterbelts could rapidly create forested networks that would increase landscape complexity and the quality and diversity of ecosystem services (Table 2 ). The goal is certainly not to make a widespread conversion of high-quality agricultural land to poplar plantations, but to use plantations and agroforestry systems judiciously where cumulative benefits would be the highest (Bentrup 2008). A more realistic objective would be to use hybrid poplars to rapidly increase forest cover to near the 30\% minimum threshold for biodiversity protection in landscapes with low forest cover.

In short, an important reform of subsidies is needed within the forestry and agricultural sectors in order to include payment for ecosystem services provided by private owners of afforested plantations and agroforestry systems because these services are currently unaccounted for (externalities) (Bull et al. 2006).

An alternative approach to hybrid poplar cultivation on forest sites could be intensive management of short-rotation native hardwood regeneration with species such as trembling aspen and balsam poplar. The economic potential of this approach should be investigated more fully even if poplar plantations are generally more productive (Jones and Grant 1983). In the temperate zone of Québec and in the northern United States, yields close to $10 \mathrm{~m}^{3} \mathrm{ha}^{-1}$ year ${ }^{-1}$ have been reported in aspen and balsam poplar stands after 40 to 50 years (Alban et al. 1978, Doucet 2000). High yields can still be reached with natural aspen regeneration on much shorter rotations (10 to 15 years) (Stiell and Berry 1986).

Regeneration silviculture of trembling aspen is also very economical because in many cases clearcutting alone will lead to satisfactory restocking (Doucet 1989). Occasionally, special treatments are needed, but those can be applied relatively easily (Doucet 1989). Therefore, compared with silvicultural costs of approximately $\$ 5500$ per ha for clearcut site hybrid poplar plantations (Dancause 2008), intensive trembling aspen silviculture will surely be much more economical and less detrimental to the environment. Native trembling aspen stands will also produce higher-quality fibre than hybrid poplar plantations because of the higher wood density of trembling aspen (Koubaa 2007).

If forest areas are to be converted to plantations, hybrid poplars are not the right choice. Native species such as red pine may be more economically sound, because red pine grows much faster than hybrid poplars on low-quality sites (Table 4). Many other species also have an equivalent yield to hybrid poplars on low-quality sites, but on longer rotations (Table 4). 
Table 4. Volume yield $\left(\mathrm{m}^{3} \mathrm{ha}^{-1} \mathrm{yr}^{-1}\right)$ for various species in relation to site quality in southern and central Québec. Data from Dancause (2008).

\begin{tabular}{|c|c|c|c|c|}
\hline \multirow[b]{2}{*}{ Species } & \multirow[b]{2}{*}{$\begin{array}{c}\text { Plantation } \\
\text { age } \\
\text { (years) }\end{array}$} & \multicolumn{3}{|c|}{ Site quality } \\
\hline & & $\begin{array}{c}\text { High } \\
\left(\mathrm{m}^{3} \mathrm{ha}^{-1}\right) \\
\text { year }^{-1}\end{array}$ & $\begin{array}{c}\text { Moderate } \\
\left(\mathrm{m}^{3} \mathrm{ha}^{-1}\right) \\
\text { year }^{-1}\end{array}$ & $\begin{array}{c}\text { Low } \\
\left(\mathrm{m}^{3} \mathrm{ha}^{-1}\right. \\
\left.\text { year }^{-1}\right)\end{array}$ \\
\hline hybrid poplar & 20 & $15-25$ & $8-12$ & $2-5$ \\
\hline red pine & 45 & 11.4 & 9 & 6.8 \\
\hline Norway spruce & 60 & 9.3 & 5 & 3.8 \\
\hline European larch & 35 & 9 & 5.5 & 2.8 \\
\hline white spruce & 50 & 7 & 5.6 & 2 \\
\hline jack pine & 40 & 6.5 & 4.8 & 3.4 \\
\hline white pine & 40 & 6 & 4 & 3 \\
\hline
\end{tabular}

Many have been seduced by the socially acceptable concept of mixed intensive plantations, an alternative approach to mono-specific plantations of exotic poplars or larches (Larix spp.) (Messier et al. 2009, Paquette and Messier 2010). However, after only nine years, afforested poplar plantations can have significant hardwood and conifer regeneration (ashes [Fraxinus spp.], white pine (Pinus strobus L.], sugar maple [Acer saccharum Marsh.], yellow birch [Betula alleghaniensis Britt.]), with hundreds of seedlings or saplings per hectare being reported in southern Québec (BoothroydRoberts 2011). These poplar plantations are far from being biological deserts or monocultures, indeed they are forest succession catalysts (Parrotta et al. 1997). In addition, some have argued that mixing hybrid poplars or exotic larches with spruces would optimize plantation yield, based on results obtained in tropical mixed plantations and theoretical models in herbaceous communities (Messier et al. 2009, Paquette and Messier 2010). However, empirical evidence from Nelson et al. (2011) shows the opposite. These authors found in the "mixture" treatment, a nonlinear exponential decay relationship $\left(R^{2}=0.68\right)$ between white spruce (Picea glauca [Moench] Voss) and hybrid poplar biomass index, showing no evidence of over-yielding in the mixed planta- tion. With both poplar and spruce having high light requirements to achieve high yield, the much faster growth rate of poplars resulted in a single-species dominance (Nelson et al. 2011). They concluded that spruce and poplar should be planted in a mosaic of pure large blocks, rather than an even dispersion of both species at the stand scale, in order to minimize pre-crown closure interaction.

So why is there the necessity to mimic forest succession by mixing poplars with hardwoods or conifers immediately at planting? This way of proceeding increases tending costs and operational constraints (Nelson et al. 2011, J. Moreau, personal communication). Later underplanting of shade-tolerant species, before or after partial canopy removal in poplar systems (Truax et al. 2000, Gardiner et al. 2004), might be a more cost-efficient and ecologically sound restoration or production strategy. It is well known that poplars often grow in pure stands following a disturbance (Dickmann and Kuzovkina 2008), so why would pure poplar plantations be so objectionable?

Finally, from an environmental perspective, practising a "soft intensive" silviculture in natural forests rather than highly intensive forest conversion to poplar plantations may be important to maintain the role of Canada's forests in climate regulation (Carlson et al. 2010). Also along these lines, afforestation and agroforestry both have a central role to play in increasing $\mathrm{C}$ storage in degraded/transformed temperate terrestrial ecosystems and riparian ecotones (Oelbermann et al. 2004, Niu and Duiker 2006, Fortier et al. 2010b).

\section{Does Québec Really Need to Adopt a Forest Zoning Approach?}

Based on the recent allowable cut, allocation and harvesting statistics (MRNF 2001-2010), the need to adopt a forest zoning management approach on public land is also questionable (Fig. 2). Although there was an obvious over-exploitation of many forest ecosystems a few years ago (Coulombe et al. 2004), this situation does not hold anymore in many parts of the province.

Since 2005, much lower quantities of wood are being harvested each year compared to the wood volumes that are allocated to industry in public forests. In 2008-2009, only $60 \%$ of

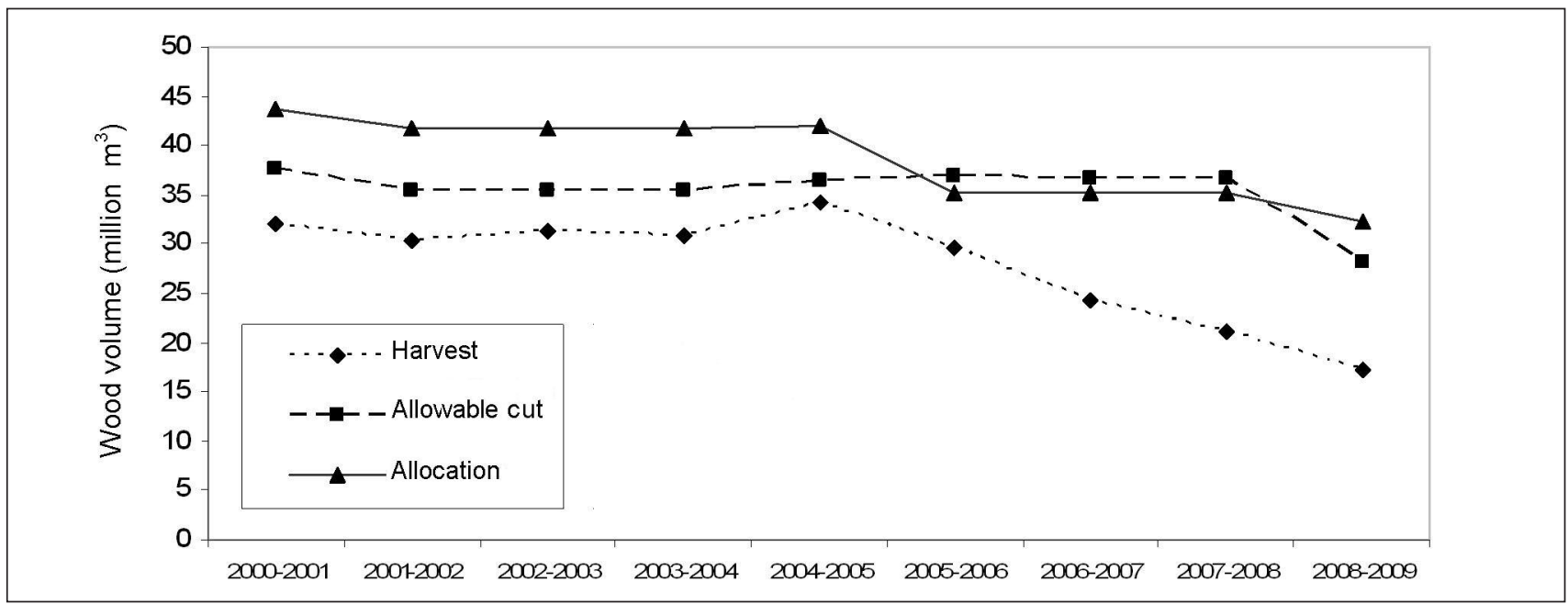

Fig. 2. Evolution of allowable cut, wood volume allocation and wood volume harvested in public forests of Québec during the २000-2009 period (MRNF 2001-2010). 
Table 5. Allowable cut $\left(\mathrm{m}^{3}\right.$ year-1) and wood volume allocated $\left(\mathrm{m}^{3}\right.$ year-1) in public forests for poplars and white birch in the different Québec regions (MRNF 2011). The percentage (\%) of wood volume from allowable cut that is allocated is also indicated for each region.

\begin{tabular}{|c|c|c|c|c|c|c|c|c|}
\hline \multirow[b]{2}{*}{ Quebec regions } & \multicolumn{4}{|c|}{ Poplars (all species) ( $\mathrm{m}^{3}$ year $\left.^{-1}\right)$} & \multicolumn{4}{|c|}{ White birch $\left(\mathbf{m}^{3}\right.$ year $\left.^{-1}\right)$} \\
\hline & Allowable cut & Allocation & Difference & $\%$ & Allowable cut & Allocation & Difference & $\%$ \\
\hline 01 - Bas-St-Laurent & 90300 & 88000 & 2300 & 97 & 111900 & 0 & 111900 & 0 \\
\hline 02 - Saguenay-Lac-St-Jean & 503800 & 463800 & 40000 & 92 & 951000 & 100000 & 851000 & 11 \\
\hline $\begin{array}{l}03 \text { - Capitale-Nationale / } \\
\text { Chaudière-Appalaches }\end{array}$ & 68000 & 52200 & 15800 & 77 & 146200 & 0 & 146200 & 0 \\
\hline 04 - Mauricie / Centre-du-Québec & 536600 & 321100 & 215500 & 60 & 829800 & 202850 & 626950 & 24 \\
\hline 07 - Outaouais & 262200 & 227439 & 34761 & 87 & 393900 & 247900 & 146000 & 63 \\
\hline 08 - Abitibi-Témiscamingue & 493900 & 347400 & 146500 & 70 & 549300 & 333500 & 215800 & 61 \\
\hline 09 - Côte-Nord & 184000 & 72250 & 111750 & 39 & 266800 & 56050 & 210750 & 21 \\
\hline 10 - Nord-du-Québec & 408300 & 252400 & 155900 & 62 & 176700 & 10800 & 165900 & 6 \\
\hline 11 - Gaspésie / Îles-de-la-Madeleine & 130000 & 94200 & 35800 & 72 & 172000 & 0 & 172000 & 0 \\
\hline $\begin{array}{l}13 \text { - Montréal / Montérégie / Laval / } \\
\text { Laurentides / Lanaudière / Estrie }\end{array}$ & 225000 & 147925 & 77075 & 66 & 424800 & 267100 & 157700 & 63 \\
\hline Total & 2902100 & 2066714 & 835386 & 71 & 4022400 & 1218200 & 2804200 & 30 \\
\hline
\end{tabular}

wood volumes allocated were actually harvested (Fig. 2). Consequently, forest "capital" is increasing in many regions of the Québec public forest. This is particularly true in many regions for soft hardwoods (aspens and white birch) that are used in sawlog, peeled and panel industries (Table 5). White birch is clearly an under-exploited resource given that only $30 \%$ of total allowable cut for this species was allocated in 2011 (MRNF 2011)(Table 5) and that harvested volumes might be even lower (see Fig. 1). In regions where poplar is less available, forest industry should take advantage of this abundant white birch resource.

We also feel that allowable cut for native poplars may increase in the future because many coniferous stands have naturally regenerated to trembling aspen following clearcutting or natural disturbances. Pre-colonial broadleaved tree abundance was 20\% in different landscapes of the Québec / Ontario clay belt region of the boreal forest, while abundance was as high as $70 \%$ a decade ago (Drapeau et al. 2000). The increase of harvesting pressure on public forests during the 2000-2005 period (Fig. 2) may result in an eventual increase in trembling aspen and paper birch abundance, particularly on till and clay deposits of the southern boreal forest. On those deposits, early successional stands are dominated by trembling aspen and intermediate successional stands are codominated by paper birch and coniferous species (Bergeron and Dubuc 1988).

Some may question, if there is an economic recovery, where are we going to take the wood? We suggest that it could be (1) by harvesting the wood surplus that already exists (Fig. 2, Table 5), (2) by implementing hybrid poplar afforestation and agroforestry on prime agricultural land and fertile abandoned farmland (see Table 3), and (3) by increasing intensive management of early-successional species (native poplars, white birch) in both southern and northern natural forest ecosystems.

So, do we really need zones of intensive fibre production in northern ecosystems to sustain timber production in order to increase protected areas and implement ecosystem manage- ment? In boreal ecosystems, intensive forest management may be more a tool to achieve ecosystem management objectives (Bergeron 2010), than a tool to implement a forest zoning approach.

A small-scale application of the forest zoning management approach in productive southern Québec ecosystems might, however, be needed to sustain local forest-related economic activity, and increase forest conservation zones in regions of high population density (Truax and Gagnon 2012). With the increasing numbers of urban inhabitants who decide to retire or reside in rural areas of southern Québec (CAAAQ 2007), and the ongoing intensification of agriculture in fertile areas (Pan et al. 1999), conflicts between forest users, urban developers and farmers will increase in the future. These conflicts could be partly resolved by promoting a zoning management approach on private lands, with most fast-growing hybrid poplar plantations (intensive wood production) located in areas of intensive agricultural activity. These areas are generally located in landscapes with very low remaining natural forest cover (Bélanger and Grenier 2002).

\section{Conclusion}

This article proposes a new perspective on the use of hybrid poplar plantations to achieve effective forest zoning management at the provincial scale in Québec. Data obtained from the literature suggest that the best opportunities for growing high-yield hybrid poplar plantations exist in riparian areas of crop fields or fertilized pastures, but also on fertile farmland and abandoned farmland sites. On those sites, poplar afforestation and agroforestry would increase wood production outside of natural forests, while increasing ecosystem services and biodiversity protection, particularly in landscapes dominated by intensive agriculture. Given their low yield and adverse effects on the environment and biodiversity, hybrid poplar plantations resulting from the conversion of natural forests should be avoided, particularly where site fertility is very low (boreal shield ecozone). Alternatively, environmentally friendly and low-cost intensive natural regener- 
ation silviculture (e.g., aspen, balsam poplar, white birch, red maple [Acer rubrum L.) on short rotations may be used to increase forest productivity in many forest ecosystems.

In the end, decision-makers, landowners and farmers must recognize that a certain level of land-use change from abandoned farmland or crop land to hybrid poplar plantations is in their best interest in the long term (Tabbush and Beaton 1998). However, for this scenario to be realized, financial incentives (e.g., carbon credits, crop insurance, $P$ credits, subsidies for planting and tending) are needed, as well as concrete legislative measures to remove the current roadblocks preventing poplar woody crops from successfully co-inhabiting agricultural landscapes with conventional crops or pastures.

\section{References}

Agence régionale de mise en valeur des forêts privées de Lanaudière. 2011. Cahier d'instructions techniques. $147 \mathrm{p}$.

Alban, D.H., D.A. Perala and B.E. Schlaegel. 1978. Biomass and nutrient distribution in aspen, pine, and spruce stands on the same soil type in Minnesota. Can. J. For. Res. 8(3): 290-299.

Allan, J.D. 2004. Landscapes and riverscapes: The Influence of Land Use on Stream Ecosystems. Ann. Rev. Ecol. Evol. Syst. 35(1): 257-284. Andrén, H. 1994. Effects of forest fragmentation on birds and mammals in landscapes with different proportions of suitable habitat: a review. Oikos 71(3): 355-366.

Archaux, F. and H. Martin. 2009. Hybrid poplar plantations in a floodplain have balanced impacts on farmland and woodland birds. For. Ecol. Manag. 257(6): 1474-1479.

Arevalo, C.B.M., J.S. Bhatti, S.X. Chang and D. Sidders. 2011. Land use change effects on ecosystem carbon balance: From agricultural to hybrid poplar plantation. Agric. Ecosyst. Environ. 141(3-4): 342-349.

Balatinecz, J.J., D.E. Kretschmann and A. Leclercq. 2001. Achievements in the utilization of poplar wood - guideposts for the future. For. Chron. 77(2): 265-269.

Ball, J., J. Carle and A.D. Lungo. 2005. Contribution of poplars and willows to sustainable forestry and rural development. Unasylva 56(221): 3-9.

BC Ministry of Agriculture Food and Fisheries. 2004. Agroforestry and speciality wood crops. Order No. 870.218-3. Available from http://www.agf.gov.bc.ca/resmgmt/fppa/refguide/commodity/870218-3_Agroforestry.pdf

Beaulieu, C. 2001. Historique des travaux de drainage au Québec et état du réseau hydrographique. Gouvernement du Québec, Ministère de l'Agriculture des Pêcheries et de l'Alimentation, Direction régionale de la Montérégie, secteur Ouest, Québec, Qc. 9 p.

Bélanger, L. and M. Grenier. 2002. Agriculture intensification and forest fragmentation in the St. Lawrence valley, Québec, Canada. Landsc. Ecol. 17(6): 495-507.

Benomar, L., A. DesRochers and G. Larocque. 2012. The effects of spacing on growth, morphology and biomass production and allocation in two hybrid poplar clones growing in the boreal region of Canada. Tree Struc. Funct. doi 10.1007/s00468-00011-00671-00466. Bentrup, G. 2008. Conservation buffers: design guidelines for buffers, corridors, and greenways. Department of Agriculture, Forest Service, Southern Research Station, Asheville, NC. 110 p.

Bergeron, Y. 2010. L'intensification de l'aménagement, un passage obligé pour laménagement écosystémique. Colloque «Laménagement forestier intensif au Québec». 17-18 mars, Québec, Qc. Available from http://www.rlq.uqam.ca/colloque/colloque2010/pdf/ 18mars_10h15_YvesBergeron.pdf

Bergeron, Y. and M. Dubuc. 1988. Succession in the southern part of the Canadian boreal forest. Plant Ecol. 79(1): 51-63.

Bigué, B., S. Delagrange, J. Fortier, F. Gaumond and F. Lorenzetti. 2011. Le peuplier hybride en Outaouais: le portrait et les hypothèses de rendement en forêt publique. Rapport final présenté à la Confé- rence régionale des Élus de l'Outaouais. Réseau Ligniculture Québec, Institut d'aménagement de la forêt feuillue, ministère des Ressources naturelles du Québec and Louisiana Pacific 52 p.

Bilodeau-Gauthier, S., D. Paré, C. Messier and N. Bélanger. 2011. Juvenile growth of hybrid poplars on acidic boreal soil determined by environmental effects of soil preparation, vegetation control, and fertilization. For. Ecol. Manag. 261(3): 620-629.

Binkley, C. 1999. Ecosystem management and plantation forestry: new directions in British Columbia. New For. 18(1): 75-88.

Bona, K.A., M.S. Burgess, J.W. Fyles, C. Camiré and P. Dutilleul. 2008. Weed cover in hybrid poplar (Populus) plantations on Quebec forest soils under different lime treatments. For. Ecol. Manag. 255(7): 2761-2770.

Boothroyd-Roberts, K. 2011. Restoring forest habitat on abandoned fields using hybrid poplar plantations: understory attributes and suitability for forest understory plants. M.Sc. Thesis, Université du Québec à Montréal.

Boysen, B. and S. Strobl. 1991. A grower's guide to hybrid poplar. Ontario Ministry of Natural Resources, Brockville, ON. 148 p.

Brockerhoff, E., H. Jactel, J. Parrotta, C. Quine and J. Sayer. 2008. Plantation forests and biodiversity: oxymoron or opportunity? Biodiv. Conserv. 17(5): 925-951.

Bull, G.Q., M. Bazett, O. Schwab, S. Nilsson, A. White and S. Maginnis. 2006. Industrial forest plantation subsidies: Impacts and implications. For. Policy Econ. 9(1): 13-31.

Bureau du forestier en chef. 2006. Possibilité forestière 2008 -2013. Résultats pour la région Outaouais / Région 07 [online]. Available from http://www.forestierenchef.gouv.qc.ca/images/stories/BFEC/ resultats/UAF/presentation-07.pdf.

Burken, J.G. and J.L. Schnoor. 1997. Uptake and metabolism of atrazine by poplar trees. Environ. Sci. Techn. 31(5): 1399-1406.

[CAAAQ] Commission sur l'avenir de l'agriculture et de l'agroenlimentaire au Québec. 2007. Agriculture et agroalimentaire: choisir l'avenir. Document de consultation $50 \mathrm{p}$.

Cann, D.B. and P. Lajoie. 1943. Études des sols des comtés de Stanstead, Richmond, Sherbrooke et Compton dans la province de Québec. Ministère de l'Agriculture, Ottawa, Canada. 58 p.

Carlson, M., J. Chen, S. Elgie, C. Henschel, Ã.l. Montenegro, N. Roulet, N. Scott, C. Tarnocai and J. Wells. 2010. Maintaining the role of Canada's forests and peatlands in climate regulation. For. Chron. 86(4): 434-443.

Carmean, W.H. 2007. Intensive plantation management for goodsite forest lands in northwest Ontario. For. Chron. 83(1): 41-53.

Chazdon, R.L. 2008. Beyond deforestation: restoring forests and ecosystem services on degraded lands. Science 320(5882): 1458-1460.

Christersson, L. 2008. Poplar plantations for paper and energy in the south of Sweden. Biomass Bioenergy 32(11): 997-1000.

Christersson, L. 2010. Wood production potential in poplar plantations in Sweden. Biomass Bioenergy 34(9): 1289-1299.

Christian, D.P. 1997. Wintertime use of hybrid poplar plantations by deer and medium-sized mammals in the midwestern U.S. Biomass Bioenergy 12(1): 35-40.

Coleman, M., D. Tolsted, T. Nichols, W.D. Johnson, E.G. Wene and T. Houghtaling. 2006. Post-establishment fertilization of Minnesota hybrid poplar plantations. Biomass Bioenergy 30(8-9): 740-749.

Cossalter, C. and C. Pye-Smith. 2003. Fast-wood forestry. Centre for International Forestry research (CIFOR), Jakarta, Indonesia. 59 p.

Costanza, R. et al. 1998. The value of the world's ecosystem services and natural capital. Ecol. Econ. 25(1): 3-15.

Côté, P., R. Tittler, C. Messier, D.D. Kneeshaw, A. Fall and M.-J. Fortin. 2010. Comparing different forest zoning options for landscape-scale management of the boreal forest: Possible benefits of the TRIAD. For. Ecol. Manag. 259(3): 418-427.

Coulombe, G., J. Huot, J. Arsenault, É. Bauce, J.-T. Bernard, A. Bouchard, M.A. Liboiron and G. Szaraz. 2004. Rapport final sur la Commission d'enquête sur la forêt publique québécoise, Québec, Qc. $306 \mathrm{p}$. 
Czapowskyj, M.M. and L.O. Safford. 1993. Site preparation, fertilization, and 10-year yields of hybrid poplar on a clearcut forest site in eastern Maine, USA. New For. 7(4): 331-344.

Dancause, A. 2008. Le reboisement au Québec. Les Publications du Québec, Québec, Qc. 177 p.

Delagrange, S. and F. Lorenzetti. 2008. Inventaire et évaluation de la performance de plantations de peupliers hybrides implantées par FPS Canada Inc. en Outaouais. Institut Québécois d'Aménagement de la Forêt feuillue, Ripon, Qc. 23 p.

DesRochers, A., R. van den Driessche and B.R. Thomas. 2006. NPK fertilization at planting of three hybrid poplar clones in the boreal region of Alberta. For. Ecol. Manag. 232(1-3): 216-225.

Dickmann, D.I. 2006. Silviculture and biology of short-rotation woody crops in temperate regions: Then and now. Biomass Bioenergy 30(8-9): 696-705.

Dickmann, D.I. and Y.A. Kuzovkina. 2008. Poplars and willows of the world, with emphasis on silviculturally important species. Rome, Italy: FAO Forest Management Division Working Paper IPC/9-2. $129 \mathrm{p}$.

Dosskey, M.G., M.J. Helmers and D.E. Eisenhauer. 2008. A design aid for determining width of filter strips. J. Soil Water Conserv. 63(4): 232-241.

Dosskey, M.G., P. Vidon, N.P. Gurwick, C.J. Allan, T.P. Duval and R. Lowrance. 2010. The role of riparian vegetation in protecting and improving chemical water quality in streams. JAWRA 46(2): 261-277.

Doucet, R. 1989. Regeneration silviculture of aspen. For. Chron. 65(1): 23-27.

Doucet, R. 2000. Effet à long terme de l'éclaircie et de la fertilisation sur la croissance de peupleraies naturelles. Note de recherche forestière $\mathrm{n}^{\circ} 108$, Direction de la recherche forestière - Forêt Québec. $10 \mathrm{p}$. Drapeau, P., A. Leduc, J.-F. Giroux, J.-P. Savard, Y. Bergeron and W.L. Vickery. 2000. Landscape-scale disturbances and changes in bird communities of boreal mixed-wood forests. Ecological Monographs 70(3): 423-444.

Duchemin, M. and J. Ménétrier. 2010. Croissance de peupliers hybrides utilisés dans un dispositif de bande végétale filtrante. Pp. 45. Congrès annuel conjoint AQSSS-SPPQ: Vers des systèmes solplante sains et durable, Oka, Qc.

Fang, S., J. Xue and L. Tang. 2007. Biomass production and carbon sequestration potential in poplar plantations with different management patterns. J. Environ. Manag. 85(3): 672-679.

Farrar, J.L. 2006. Les arbres du Canada. Fides et le Service canadien des forêts, Ressources naturelles Canada, St-Laurent, Qc. 502 p.

Fortier, J., D. Gagnon, B. Truax and F. Lambert. 2010a. Biomass and volume yield after 6 years in multiclonal hybrid poplar riparian buffer strips. Biomass Bioenergy 34(7): 1028-1040.

Fortier, J., D. Gagnon, B. Truax and F. Lambert. 2010b. Nutrient accumulation and carbon sequestration in 6 year-old hybrid poplars in multiclonal agricultural riparian buffer strips. Agric. Ecosyst. Environ. 137(3-4): 276-287.

Fortier, J., D. Gagnon, B. Truax and F. Lambert. 2011. Understory plant diversity and biomass in hybrid poplar riparian buffer strips in pastures. New For. 42(2): 241-265.

Fortier, J. and C. Messier. 2006. Are chemical or mechanical treatments more sustainable for forest vegetation management in the context of the TRIAD? For. Chron. 82(6): 806-818.

Francoeur, L.G. 2006. 71 lacs contaminés au Québec. Le Devoir, 17 october.

FSC. 2004. Norme boréale nationale. Available from http://www.fsccanada.org/docs/norme\%20bor\%C3\%A9ale\%20nationale.pdf?LanguageID=EN-US.

Gardiner, E.S., J.A. Stanturf and C.J. Schweitzer. 2004. An afforestation system for restoring bottomland hardwood forests: biomass accumulation of nuttall oak seedlings interplanted beneath eastern cottonwood. Rest. Ecol. 12(4): 525-532.
Gelhaye, D., J. Ranger and M. Bonneau. 1997. Biomass and nutrient content of a short rotation coppice of Beaupre poplars planted on a non-alluvial acidic soil improved by fertilization. Ann. For. Sc. 54(7): 649-665.

Giani, A., D.F. Bird, Y.T. Prairie and J.F. Lawrence. 2005. Empirical study of cyanobacterial toxicity along a trophic gradient of lakes. Can. J. Fish. Aquatic Sc. 62(9): 2100-2109.

González-García, S., C.M. Gasol, X. Gabarrell, J. Rieradevall, M.T. Moreira and G. Feijoo. 2010. Environmental profile of ethanol from poplar biomass as transport fuel in Southern Europe. Renew. Energy 35(5): 1014-1023.

Gouvernement du Québec. 2008. La forêt, pour construire le Québec de demain. Livre vert. 73 p.

Gregory, S.V., F.J. Swanson, W.A. McKee and K.W. Cummins. 1991. An ecosystem perspective of riparian zones. BioSc. 41(8): 540-551.

Guillemette, T. and A. DesRochers. 2008. Early growth and nutrition of hybrid poplars fertilized at planting in the boreal forest of western Quebec. For. Ecol. Manag. 255(7): 2981-2989.

Hanson, E.A. 1994. A guide for determining when to fertilize hybrid poplar plantations. USDA Forest Service, North Central Forest Experimental Station. Res. Pap. NC-319. 7 p.

Hartley, M.J. 2002. Rationale and methods for conserving biodiversity in plantation forests. For. Ecol. Manag. 155(1-3): 81-95.

Hartmann, H., G. Daoust, B. Bigué and C. Messier. 2010. Negative or positive effects of plantation and intensive forestry on biodiversity: A matter of scale and perspective. For. Chron. 86(3): 354-364.

Haruki, M. and S. Tsuyuzaki. 2001. Woody plant establishment during the early stages of volcanic succession on Mount Usu, northern Japan. Ecological Research 16(3): 451-457.

Haycock, N.E. and G. Pinay. 1993. Groundwater nitrate dynamics in grass and poplar vegetated riparian buffer strips during the winter. J. Environ. Qual. 22(2): 273-278.

Heilman, P. and R.J. Norby. 1998. Nutrient cycling and fertility management in temperate short rotation forest systems. Biomass Bioenergy 14(4): 361-370.

Hendrickson, O.Q., L. Chatarpaul and D. Burgess. 1989. Nutrient cycling following whole-tree and conventional harvest in northern mixed forest. Can. J. For. Res. 19(6): 725-735.

Hunter, M.L. 1990. Wildlife, forest and forestry - principles for managing forest for biodiversity. Prentice Hall, Englewood Cliffs, NJ. $370 \mathrm{p}$.

Isebrands, J.G. and D.F. Karnosky. 2001. Environmental benefits of poplar culture In D.I. Dickmann, J.G. Isebrands, J.E. Eckenwalder and J. Richardson (eds.). Poplar Culture in North America. Part A, Chapter 6. pp. 207-218. NRC Research Press, National Research Council of Canada, Ottawa, ON.

Jandl, R., M. Lindner, L. Vesterdal, B. Bauwens, R. Baritz, F. Hagedorn, D.W. Johnson, K. Minkkinen and K.A. Byrne. 2007. How strongly can forest management influence soil carbon sequestration? Geoderma 137(3-4): 253-268.

Johnson, D.W. and P.S. Curtis. 2001. Effects of forest management on soil C and N storage: meta analysis. For. Ecol. Manag. 140(2-3): 227-238.

Jones, A.R.C. and J. Grant. 1983. Hybrid poplars or hardwood coppice? An agriforestry option to economically increasing wood production in Eastern Canada. For. Chron. 59(3): 143-145.

Jordahl, J.L., L. Foster, J.L. Schnoor and P.J.J. Alvarez. 1997. Effect of hybrid poplar trees on microbial populations important to hazardous waste bioremediation. Environmental Toxicology and Chemistry 16(6): 1318-1321.

Joss, B., R. Hall, D. Sidders and T. Keddy. 2008. Fuzzy-logic modeling of land suitability for hybrid poplar across the Prairie Provinces of Canada. Environmental Monitoring and Assessment 141(1): 79-96.

Kelly, J., J. Kovar, R. Sokolowsky and T. Moorman. 2007. Phosphorus uptake during four years by different vegetative cover types in a riparian buffer. Nutr. Cycl. Agroecosyst. 78(3): 239-251. 
Koubaa, A. 2007. Les peupliers hybrides et les mélèzes exotiques: les pistes de valorisation. La Stratégie d'investissements sylvicoles au Québec : où se situe la ligniculture ? $75^{\text {th }}$ ACFAS congress, TroisRivières, Qc.

Labrecque, J. 2009. Indicator species of soil nutrients and poplar plantation productivity in southeastern Quebec. M.Sc. Thesis. Department of Natural Resource Sciences. McGill University, Montréal, QC. 115 p.

Lal, R., J.A. Delgado, P.M. Groffman, N. Millar, C. Dell and A. Rotz. 2011. Management to mitigate and adapt to climate change. J. Soil Water Conserv. 66(4): 276-285.

Lapointe, E. 2010. La ligniculture au Québec: une partie intégrante de l'aménagement forestier durable chez Domtar. Colloque «Laménagement forestier intensif au Québec». 17-18 mars, Québec, Qc. Available from http://www.rlq.uqam.ca/colloque/colloque2010/pdf/ 18mars_9h15_EricLapointe.pdf.

Lautenschlager, R.A. 2000. Can intensive silviculture contribute to sustainable forest management in northern ecosystems? For. Chron. 76(2): 283-295.

Le Floch, S. 2002. Les «ramiers»: un espace riverain inaccessible de la Garonne? Ethno. Fr. 32(4): 719-726.

Licht, L.A. 1992. Salicaceae family trees in sustainable agroecosystems. For. Chron. 68(2): 214-217.

Licht, L.A. and J.G. Isebrands. 2005. Linking phytoremediated pollutant removal to biomass economic opportunities. Biomass Bioenergy 28(2): 203-218.

Lteif, A., J.K. Whalen, R.L. Bradley and C. Camiré. 2007. Mixtures of papermill biosolids and pig slurry improve soil quality and growth of hybrid poplar. Soil Use Manag. 23(4): 393-403.

Lust, N., T. Kongs, L. Nachtergale and L. De Keersmaeker. 2001. Spontaneous ingrowth of tree species in poplar plantations in Flanders. Ann. For. Sc. 58(8): 861-868.

Mao, R., D.-H. Zeng, Y.-L. Hu, L.-J. Li and D. Yang. 2010. Soil organic carbon and nitrogen stocks in an age-sequence of poplar stands planted on marginal agricultural land in Northeast China. Plant Soil 332(1): 277-287.

MAPAQ. 2005. Description statistique des propriétés chimiques des sols minéraux du Québec. Institut de recherche et de développement en agroenvironnement (IRDA). $108 \mathrm{p}$.

Marchand, P. and S. Masse. 2007. Boisement et agroforesterie en courtes rotations en territoire privé au Québec : Examen des lois, règlements, politiques et programmes. Ressource Naturelle Canada, Service canadien des forêts, Centre de foresterie des Laurentides. $64 \mathrm{p}$. Martin, C.W. and J.W. Hornbeck. 1989. Revegetation after strip cutting and block clearcutting in northern hardwoods: a 10-year history. USDA For. Serv. Res. Rep. NE-625.

Mattson, W.J., E.A. Hart and W.J.A. Volney. 2001. Insects pests of Populus: copping with the inevitable, Part A, Chapter 7 In D.I. Dickmann, J.G. Isebrands, J.E. Eckenwalder and J. Richardson (eds.). Poplar culture in North America. pp. 219-248. NRC Research Press, National Research Council of Canada, Ottawa, ON

McWilliam, E.L., T.N. Barry, N. Lopez-Villalobos, P.N. Cameron and P.D. Kemp. 2004. The effect of different levels of poplar (Populus) supplementation on the reproductive performance of ewes graz ing low quality drought pasture during mating. Anim. Feed Sci. Techn. 115(1-2): 1-18.

Ménétrier, J. 2008. Le peuplier hybride au Québec : une révolution, une évolution. Natur. Can. 132(1): 46-54.

Ménétrier, J., M. Perron, G. Daoust and G. Sirois. 2005. Le boisement des friches. Notice d'information. Gouvernement du Québec, Ministère des Ressources naturelles et de la Faune, Direction de la recherche forestière et Ressources naturelles Canada, Service canadien des forêts, Centre de foresterie des Laurentides. 29 p. Available from http://www.mrnf.gouv.qc.ca/publications/forets/connaissances/ recherche/Menetrier-Jean/Foret-2020-Boisement-friche.pdf.

Messier, C., B. Bigué and L. Bernier. 2003. Using fast-growing plantations to promote forest ecosystem protection in Canada. Unasylva 54(214-215): 59-63.
Messier, C., R. Tittler, D.D. Kneeshaw, N. Gélinas, A. Paquette, K. Berninger, $H$. Rheault, P. Meek and N. Beaulieu. 2009. TRIAD zoning in Quebec: Experiences and results after 5 years. For. Chron. 85(6): 885-896.

Montigny, M.K. and D.A. MacLean. 2006. Triad forest management: Scenario analysis of forest zoning effects on timber and nontimber values in New Brunswick, Canada. For. Chron. 82(4): 496-511. Moreau, J. 2008. Comparaison des rendements de 2 clones de peupliers hybrides âgés de 6 ans à Lavaltrie. Projet de fin détude en aménagement :FOR20167. Université Laval, Québec, QC. 54 p.

Morissette, S. 2012. Superficies de peuplier hybride en production au Québec. Ligne et culture 11(1): 8.

[MRNF] Ministère des Ressources naturelles et de la Faune. 2001-2010. Statistiques forestières. Ressource et Industries forestières: portrait statistique édition (2001 to 2010). Available from http://www.mrnf.gouv.qc.ca/publications/forets/connaissances/stat _edition_complete/preface.pdf and http://www.mrnf.gouv.qc.ca/ forets/connaissances/connaissances-statistiques-anterieures.jsp.

2011. Synthèse des possibilités forestières et des attributions par région et par essence. Available from http://www.mrn.gouv.qc.ca/ forets/amenagement/CAAF-pdf/synthese/p_a_qc.pdfp.

Naiman, R.J., H. Décamps and M.E. McClain. 2005. Riparia. Elsevier Academic Press, Burlington, MA. 430 p.

Natural Resources Canada. 2011. The state of Canada's forests Annual report 2011. 54 p. Available from http://cfs.nrcan.gc.ca/pubwarehouse/pdfs/32683.pdf.

Nelson, A.S., Saunders, M.R., Wagner, R.G. and A.R. Weiskittel. 2011. Early stand production of hybrid poplar and white spruce in mixed and monospecific plantations in eastern Maine. New For. 43(4):519-534.

Niu, X. and S.W. Duiker. 2006. Carbon sequestration potential by afforestation of marginal agricultural land in the Midwestern U.S. For. Ecol. Manag. 223(1-3): 415-427.

Oelbermann, M., P.R. Voroney and A.M. Gordon. 2004. Carbon sequestration in tropical and temperate agroforestry systems: a review with examples from Costa Rica and southern Canada. Agric. Ecosyst. Environ. 104(3): 359-377.

Pan, D., G. Domon, S. de Blois and A. Bouchard. 1999. Temporal (1958-1993) and spatial patterns of land use changes in Haut-SaintLaurent (Quebec, Canada) and their relation to landscape physical attributes. Landsc. Ecol. 14(1): 35-52.

Paquette, A. and C. Messier. 2010. The role of plantations in managing the world's forests in the Anthropocene. Frontiers Ecol. Environ. 8(1): 27-34.

Park, A. and E.R. Wilson. 2007. Beautiful Plantations: Can intensive silviculture help Canada to fulfill ecological and timber production objectives? For. Chron. 83(6): 885-896.

Parrotta, J.A., J.W. Turnbull and N. Jones. 1997. Catalyzing native forest regeneration on degraded tropical lands. For. Ecol. Manag. 99(1-2): 1-7.

Périnet, P. 2007. Le programme d'amélioration génétique du peuplier au Québec. In P. Périnet, M. Perron and P. Bélanger (eds.). La populiculture : un projet collectif, du clone à l'usine. Guide des visites de terrain. Réunion annuelle $2007 \mathrm{du}$ Conseil du peuplier du Canada. pp. 11-12. Conseil du peuplier du Canada and Ministère des Ressources naturelles et de la Faune du Québec, Direction de la recherche forestière, Québec, Qc.

Périnet, P., H. Gagnon and S. Morin. 2008. Liste des clones recommandés de peuplier hybride par sous-région écologique au Québec (révision février 2008). Direction de la recherche forestière, MRN, Québec. $1 \mathrm{p}$.

Perry, C.H., R.C. Miller and K.N. Brooks. 2001. Impacts of shortrotation hybrid poplar plantations on regional water yield. For. Ecol. Manag. 143(1-3): 143-151.

Petrinovic, N., J.F. Gélinas and J. Beaulieu. 2009. Rentabilité des plantations dépinette blanche améliorée génétiquement au Québec : le point de vue du propriétaire. For. Chron. 85(4): 558-570. 
Pinno, B.D., D. Paré, L. Guindon and N. Bélanger. 2009. Predicting productivity of trembling aspen in the Boreal Shield ecozone of Quebec using different sources of soil and site information. For. Ecol. Manag. 257(3): 782-789.

Pliura, A., S.Y. Zhang, J. MacKay and J. Bousquet. 2007. Genotypic variation in wood density and growth traits of poplar hybrids at four clonal trials. For. Ecol. Manag. 238(1-3): 92-106.

Popova, M., V. Bankova, S. Bogdanov, I. Tsvetkova, C. Naydenski, G. Marcazzan and A.-G. Sabatini. 2007. Chemical characteristics of poplar type propolis of different geographic origin. Apidologie 38(3): 306-311.

Québec. 2011a. Loi sur l'aménagement durable du territoire forestier. L.R.Q., chapitre A-18.1. Éditeur officiel du Québec.

Québec. 2011b. Loi sur les pesticides, L.R.Q., c P-9.3é Éditeur officiel du Québec

Québec. 2011c. Règlement sur les exploitations agricoles. c. Q-2, r.11.1. Éditeur officiel du Québec.

Riemenschneider, D.E., B.J. Stanton, G. Vallée and P. Périnet. 2001. Poplar breeding strategies. Part A, Chapter 2. In D.I. Dickmann, J.G. Isebrands, J.E. Eckenwalder and J. Richardson (eds.). Poplar culture in North America. pp. 43-76. NRC Research Press, National Research Council of Canada, Ottawa, ON.

Robitaille, A. and J.-P. Saucier. 1998. Paysages régionaux du Québec méridional. Les publications du Québec, Ste-Foy, QC. 213 p.

Rockwood, D.L., C.V. Naidu, D.R. Carter, M. Rahmani, T.A. Spriggs, C. Lin, G.R. Alker, J.G. Isebrands and S.A. Segrest. 2004. Short-rotation woody crops and phytoremediation: Opportunities for agroforestry? Agrofor. Syst. 61-62(1): 51-63.

Schimel, J.P., R.G. Cates and R. Ruess. 1998. The role of balsam poplar secondary chemicals in controlling soil nutrient dynamics through succession in the Alaskan Taiga. Biogeochem. 42(1): 221-234.

Schmidt, M.G., S.E. Macdonald and R.L. Rothwell. 1996. Impacts of harvesting and mechanical site preparation on soil chemical properties of mixed-wood boreal forest sites in Alberta. Can. J. Soil Sci. 76(4): 531-540.

Schroeder, W., S. Silim, J. Patterson Fradette and H. de Grooijer. 2003. Detailed site analysis and mapping of agroforestry potential in the northern agricultural zone of Saskatchewan. Agriculture and Agri-Food Canada, Final Report to Saskatchewan Forestry Centre. Schultz, R.C., T.M. Isenhart, W.W. Simpkins and J.P. Colletti. 2004. Riparian forest buffers in agroecosystems - lessons learned from the Bear Creek Watershed, central Iowa, USA. Agrofor. Syst. 61-62(1): 35-50.

Schweitzer, J. et al. 2008. From genes to ecosystems: the genetic basis of condensed tannins and their role in nutrient regulation in a Populus model system. Ecosyst. 11(6): 1005-1020.

Singh, B. and K. Sharma. 2007. Nutrition and growth of wheat-sorghum rotation in soils amended with leaf litter of trees before planting of wheat. Agrofor. Syst. 71(1): 25-34.

Stanturf, J.A., C. van Oosten, M.D. Coleman and C.J. Portwood. 2001. Ecology and silviculture of poplar plantations. In D.I. Dickmann, J.G. Isebrands, J.E. Eckenwalder and J. Richardson (eds.). Poplar culture in North America. pp. 153-206. NRC Research Press, National Research Council of Canada, Ottawa, ON.

Statistique Canada. 2008. Superficie agricole totale, mode d'occupation et terres en culture, par province (Recensements de l'agriculture de 1986 à 2006).

Stephenson, J.M. and A. Morin. 2009. Covariation of stream community structure and biomass of algae, invertebrates and fish with forest cover at multiple spatial scales. Freshw. Biol. 54(10): 2139-2154

Stiell, W.M. and A.B. Berry. 1986. Productivity of short rotation aspen stands. For. Chron. 62(1): 10-15.
Sweeney, B.W., T.L. Bott, J.K. Jackson, L.A. Kaplan, J.D. Newbold, L.J. Standley, W.C. Hession and R.J. Horwitz. 2004. Riparian deforestation, stream narrowing, and loss of stream ecosystem services. PNAS 101(39): 14132-14137.

Tabbush, P. and A. Beaton. 1998. Hybrid poplars: present status and potential in Britain. For. 71(4): 355-364.

Thompson, I.D., J.A. Baker and M. Ter-Mikaelian. 2003. A review of the long-term effects of post-harvest silviculture on vertebrate wildlife, and predictive models, with an emphasis on boreal forests in Ontario, Canada. For. Ecol. Manag. 177(1-3): 441-469.

Timmer, V.R. 1985. Response of a hybrid poplar clone to soil acidification and liming. Can. J. Soil Sc. 65(4): 727-735.

Truax, B. and D. Gagnon. 2012. Application du zonage forestier (Triade) dans la forêt feuillue privée du sud du Québec. Les colloques du SCF-CFL. March 29, 2012. Québec (Qc). Available from http://www.partenariat.qc.ca/videoconferences/presentation_b_ truax_29\%20mars\%202012.pdf

Truax, B., D. Gagnon, J. Fortier and F. Lambert. 2012. Yield in 8 year-old hybrid poplar plantations on abandoned farmland along climatic and soil fertility gradients. For. Ecol. Manag. 267(March): 228-239.

Truax, B., F. Lambert and D. Gagnon. 2000. Herbicide-free plantations of oaks and ashes along a gradient of open to forested mesic environments. For. Ecol. Manag. 137(1-3): 155-169.

Tscharntke, T., A.M. Klein, A. Kruess, I. Steffan-Dewenter and C. Thies. 2005. Landscape perspectives on agricultural intensification and biodiversity - ecosystem service management. Ecol. Lett. 8(8): 857-874.

Tufekcioglu, A., J.W. Raich, T.M. Isenhart and R.C. Schultz. 2001. Soil respiration within riparian buffers and adjacent crop fields. Plant Soil 229(1): 117-124.

Tufekcioglu, A., J.W. Raich, T.M. Isenhart and R.C. Schultz. 2003. Biomass, carbon and nitrogen dynamics of multi-species riparian buffers within an agricultural watershed in Iowa, USA. Agrofor. Syst. 57(3): 187-198.

Updegraff, K., M.J. Baughman and S.J. Taff. 2004. Environmental benefits of cropland conversion to hybrid poplar: economic and policy considerations. Biomass Bioenergy 27(5): 411-428.

Vardar-Ünlü, G., S. Silici and M. Ünlï. 2008. Composition and in vitro antimicrobial activity of Populus buds and poplar-type propolis. World J. Microbiol. Biotech. 24(7): 1011-1017.

Vouligny, C. and S. Gariepy. 2008. Les friches agricoles au Québec: état des lieux et approches de valorisation. Agriculture et Agroalimentaire Canada, Québec, Qc. 66 p.

Weih, M., A. Karacic, H. Munkert, T. Verwijst and M. Diekmann. 2003. Influence of young poplar stands on floristic diversity in agricultural landscapes (Sweden). Bas. App. Ecol. 4(2): 149-156.

Yemshanov, D. and D. McKenney. 2008. Fast-growing poplar plantations as a bioenergy supply source for Canada. Biomass Bioenergy 32(3): 185-197.

Young, H.E., J.H. Ribe and D.C. Hoppe. 1979. A biomass study of the thinning potential and productivity of immature forest stands in Maine. Maine Life Sci. and Agri. Exp. Sta. Bull. No. 758.

Zabek, L.M. and C.E. Prescott. 2006. Biomass equations and carbon content of aboveground leafless biomass of hybrid poplar in Coastal British Columbia. For. Ecol. Manag. 223(1-3): 291-302.

Zaimes, G.N., R.C. Schultz and T.M. Isenhart. 2004. Stream bank erosion adjacent to riparian forest buffers, row-crop fields, and continuously-grazed pastures along Bear Creek in central Iowa. J. Soil Water Conserv. 59(1): 19-27.

Zsuffa, L., H.W. Anderson and P. Jaciw. 1977. Trends and prospects in Ontario's poplar plantation management. For. Chron. 53(5): 195-200. 